\title{
Palaeoenvironmental dynamics of Holocene shoreface bryoliths from the southern coast of Brazil
}

\author{
Frederico Tapajós de Souza Tâmega, ' (iD) Paula Spotorno-Oliveira,' \\ Paula Dentzien-Dias, ' Francisco Sekiguchi Buchmann, ${ }^{2}$ \\ Leandro Manzoni Vieira, ${ }^{3}$ Kita Macario, 4 (D) Merinda Nash, ${ }^{5}$ \\ Renato Bastos Guimarães, ${ }^{6}$ Heitor Francischini ${ }^{7}$ and Davide Bassi ${ }^{8}$
}

\begin{abstract}
Beds of free-living coated nodules (coralline algae, bryozoans, acervulinid foraminifera) create shallow-water carbonate biogenic benthic habitats, which are sensitive to human disturbance and slow to recover. Holocene bryoliths, ranging from sub-spheroidal, sub-discoidal to sub-ellipsoidal in shape, were found scattered in the foredunes in ca. 30-km stretch along the Hermenegildo and Concheiros do Albardão beaches on the southernmost coast of Brazil (Santa Vitória do Palmar municipality, Rio Grande do Sul State). The dominating bryozoan species forming the bryolith is Biflustra holocenica Vieira, Spotorno-Oliveira and Tâmega sp. nov. The inner bryolith arrangement, generally asymmetrical, shows multilamellar and circumrotatory growth of colonies that envelop the bivalve Ostrea puelchana. Bryozoans and subordinate corals characterize the outer bryolith surfaces. The ichnogenera Gastrochaenolites (made by the boring bivalve Lithophaga patagonica) and Caulostrepsis occur throughout the bryoliths, from the inner part up to the outer surface. The studied bryoliths, originated in a shoreface setting at ca. 7910-7620 cal. yr BP and during subsequent storm waves, were resedimented onto the foreshore and foredunes (to ca. 5700 cal. yr BP) where the bryoliths were finally fossilized.
\end{abstract}

\section{Keywords}

Brazil, Bryozoa, Holocene, palaeoecology, taxonomy

Received II March 20I8; revised manuscript accepted I2 December 2018

\section{Introduction}

Beds of free-living nodules are built by marine encrusting calcareous organisms growing around a hard nucleus on mobile substrates and are overturned by waves, currents or bioturbation (e.g. Moissette et al., 2010; Prager and Ginsburg, 1989). Macroids (i.e. macrooncoids or large oncoids), organic, centimetre-sized $(>10 \mathrm{~mm})$ coated grains, are formed predominantly by encrusting metazoans or protozoans, sometimes associated with calcareous algae (Bassi et al., 2012; Hottinger, 1983; Peryt, 1983). The beds provide a stable habitat on which seaweeds, coralline red algae and invertebrates can thrive. Fossil and modern free-living nodules made predominantly of a single species of an encrusting sclerobiont include rhodoliths formed by coralline algae (e.g. Aguirre et al., 2017; Baarli et al., 2012; Bosence, 1983), coralliths by corals (e.g. Glynn, 1974), bryoliths by bryozoans (ectoproctaliths, bryoncoids, bryooids; for example, Nebelsick, 1996; Scholz, 2000) and ostreoliths by oysters (Wilson et al., 1998).

Bryoliths formed by cheilostome and cyclostome bryozoans are found on sand and shell-gravel substrates (James et al., 2006). Among cheilostomes, the main taxa producing bryoliths are antroporids (Nishizawa, 1985), celleporids (El-Sorogy, 2015; Nebelsick, 1996; Spjeldnaes and Moissette, 1997), membraniporids (Kidwell and Gyllenhaal, 1998; Klicpera et al., 2013), microporids (Moissette et al., 2010), schizoporellids (Zabin et al., 2010) and smittinids (James et al., 2006). Several bryolithforming taxa have been reported from the Miocene: Cellepora sp. (El-Sorogy, 2015; Nebelsick, 1996), Celleporina sp., Cerioporidae sp., Tetrocycloecia sp. (El-Sorogy, 2015, as Tretocycloecia)

'Programa de Pós-Graduação em Oceanografia Física, Química e Geológica, Instituto de Oceanografia, Universidade Federal do Rio Grande, Brazil

${ }^{2}$ Laboratório de Estratigrafia e Paleontologia, Campus do Litoral Paulista, Universidade Estadual Paulista, Brazil

${ }^{3}$ Laboratório de Estudos de Bryozoa (LAEBry), Departamento de

Zoologia, Centro de Biociências, Universidade Federal de Pernambuco, Brazil

4Laboratório de Radiocarbono, Instituto de Física, Universidade Federal Fluminense, Brazil

${ }^{5}$ Research School of Earth Sciences, The Australian National University, Australia

'Laboratório de Difração de Raios X (LDRX-UFF), Instituto de Física, Universidade Federal Fluminense, Brazil

'Instituto de Geociências, Universidade Federal do Rio Grande do Sul, Brazil

${ }^{8}$ Dipartimento di Fisica e Scienze della Terra, Università degli Studi di Ferrara, Italy

\section{Corresponding author:}

Frederico Tapajós de Souza Tâmega, Programa de Pós-Graduação em Oceanografia Física, Química e Geológica, Instituto de Oceanografia, Universidade Federal do Rio Grande, Av. Itália, Km 8, Rio Grande 96203-900, Rio Grande do Sul, Brazil.

Email: fredtamega@gmail.com 

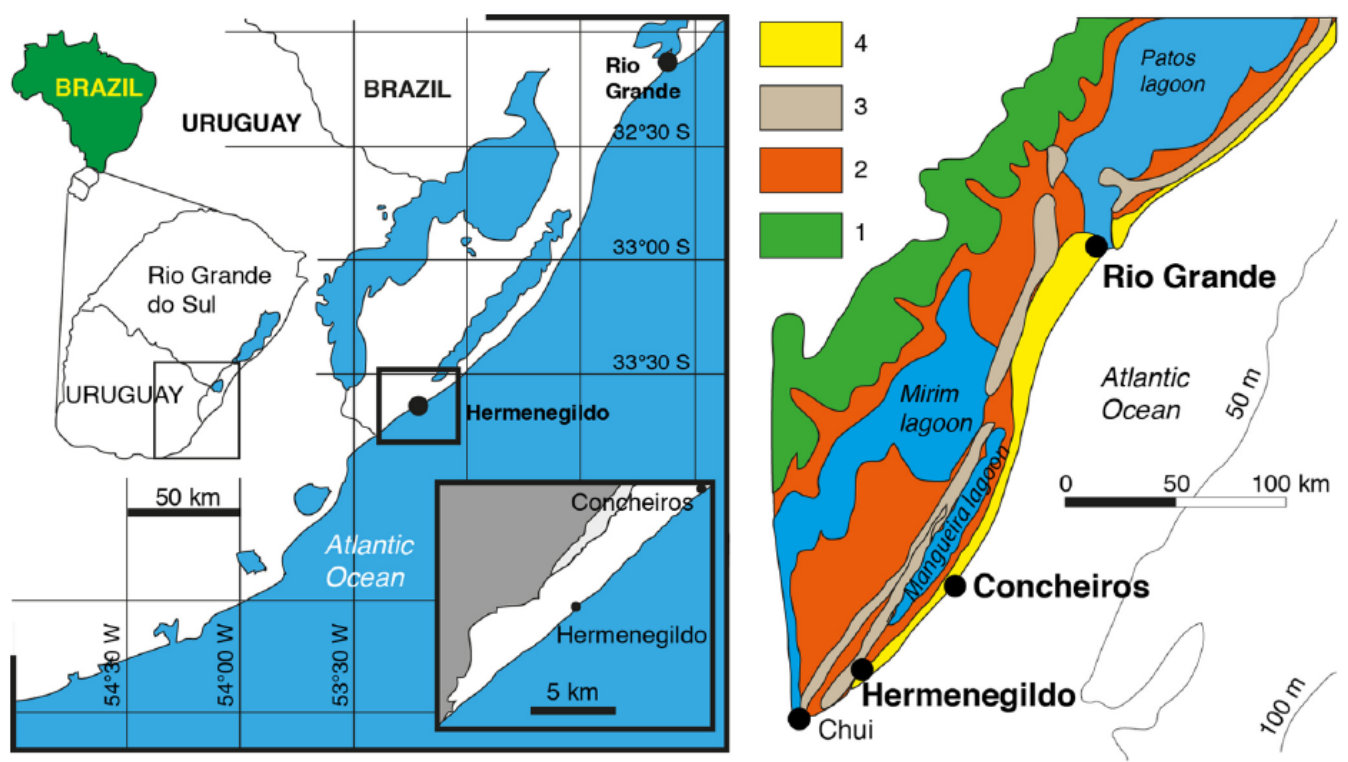

Figure I. Geographic (left) and geological (right) location on the studied area (Hermenegildo and Concheiros do Albardão beaches), Rio Grande do Sul, Brazil. I, alluvial lake system; 2, Holocene/Pleistocene lagoonal system; 3, Pleistocene barrier; 4, Holocene barrier (modified from Rosa et al., 2017; Tomazelli and Villwock, 1996).

and Turbicellepora sp. (El-Sorogy, 2015; Nebelsick, 1996). Conopeum commensale (Kirkpatrick and Metzelaar, 1922) has been reported both from the Pliocene (Cuffey and Johnson, 1997; Kidwell and Gyllenhaal, 1998; Moissette et al., 2010) and the present day (Klicpera et al., 2013).

The modern Brazilian continental shelf from $3^{\circ}$ to $22^{\circ} \mathrm{S}$ is considered the largest area in the world supporting rhodolith beds (Foster, 2001), ranging in depth from 20 to $250 \mathrm{~m}$ (Henriques et al., 2014; Kempf, 1980; Kempf et al., 1969). Pleistocene-to-Recent bryozoan counterparts of the rhodolith beds have been recently studied. In Rio de Janeiro State, Tâmega et al. $(2013,2014)$ reported a number of bryozoan taxa associated with fossil Holocene (4 spp.) and recent rhodolith beds (20 spp.) surveyed from 94 to $105 \mathrm{~m}$ water depth. Barbosa (1967) recognized one single undated bryolith formed by Conopeum commensale collected in the Concheiros do Albardão beach, Santa Vitória do Palmar, Rio Grande do Sul State (RS), Brazil. The bryolith is associated with Pleistocene and Holocene vertebrate remains (e.g. fishes and mammals). Ramalho and Calliari (2015) described eight bryozoan species occurring on the RS shoreface from 12 to $21 \mathrm{~m}$ water depth.

In this study, we report for the first time the occurrence of Holocene bryoliths from the southern Brazilian coast at $33^{\circ} \mathrm{S}$. The bryoliths are characterized in terms of growth forms, inner arrangement and taxonomic composition, including the description of a new bryozoan species. The palaeoecological analysis of these fossil bryoliths assesses their palaeoenvironmental dynamics recorded in the Hermenegildo and Concheiros do Albardão sedimentary deposits over the past 7900 years.

\section{Study sites}

This study was carried out at the Hermenegildo $\left(33^{\circ} 32^{\prime} 49^{\prime \prime} \mathrm{S}\right.$, $53^{\circ} 06^{\prime} 28^{\prime \prime} \mathrm{W}$ ) and Concheiros do Albardão (33⒊ $31^{\prime} 49^{\prime \prime} \mathrm{S}, 53^{\circ} 05^{\prime} 13^{\prime \prime}$ W) beaches, Santa Vitória do Palmar, RS, Brazil (Figure 1). These beaches are characterized by fine to medium sand in summer (aggregation profile) and mixed composition of coarse sand and bioclastic gravel in winter (erosion profile; Asp et al., 1999; Dillenburg et al., 2004).

These studied sites belong to the Rio Grande do Sul State coastal plain (RSCP), which is Neogene-Quaternary in age and broadens along the $615 \mathrm{~km}$ length (Tomazelli et al., 2000).
In the northern and southern ends of the RSCP, shorefaces are completely different. The southern part of the Lagoa dos Patos inlet (Figure 1) has a gradually decreasing slope towards the sea (Fachin, 1998). The extensive and shallow upper shoreface has a boundary at $10 \mathrm{~m}$ water depth with predominantly gravel and sand deposits, whereas the lower shoreface has a boundary at $40 \mathrm{~m}$ depth with predominantly fine sand deposits (Toldo et al., 2006). The average significant wave height and period are $1 \mathrm{~m}$ and 10-11 s, respectively (Tozzi and Calliari, 2000). During autumn and winter storms, wave height frequently exceeds $2 \mathrm{~m}$ and storm surges can reach up to $1.3 \mathrm{~m}$ above the modern mean sea level (MSL; Calliari et al., 1998; Parise et al., 2009).

The RS shoreface and inner shelf are characterized by gently steepened bedding, the most prominent features of which are linear sand shoals, marine terraces and exposed hard bottoms of beach rocks. There is no current sediment input, only biogenic contribution by biofouling and platform mud (Buchmann et al., 2001; Buchmann and Tomazelli, 2003). The submerged Pleistocene-Holocene beach rocks are constituted essentially by carbonate rocks. The RSCP is characterized by several marine and continental fossil deposits located both on the continental shelf (Buchmann, 1994; Figueiredo, 1975) and in continental areas landwards of the present-day coastline (Lopes, 2013). On the inner shelf, predominantly Holocene mollusc shell deposits (Ritter et al., 2017) are exposed during autumn and winter erosive events by strong storm waves produced by the passage of extratropical cyclones and transported to the beach (Cruz et al., 2016).

\section{Methods}

\section{Sampling methods, bryolith shapes and composition}

The bryoliths were found scattered along the foreshore and foredunes, between Hermenegildo and Concheiros do Albardão beaches (Figure 1). A total of 36 bryoliths were collected. To determine the biotic differences from the inner to the outer bryolith parts, the relative coverage of bryoliths and faunal components were estimated by point-counting ( 50 random points) on photographed 36 bryolith specimens using the image analysis program Coral Point Count with Excel extensions (CPCe; Kohler and Gill, 2006). The measurements of the long, intermediate and short orthogonal axes were taken from each bryolith to determine 
the sphericity, illustrated by the Triangular Diagram Plotting Spreadsheet (TRI-PLOT; Graham and Midgley, 2000). The amount of boring with respect to the original bryolith arrangement was defined by the bioerosion index (BI; Bassi et al., 2012).

The taxonomic composition and relative cover of the bryolith builders were assessed by one-way analysis of variance (ANOVA; Sokal and Rohlf, 1995). Significant differences were investigated via the Tukey test (Zar, 1999). Bryozoan taxonomic identification was carried out by scanning electron microscopy (SEM) analysis at the Centro de Microscopia Eletrônica do Sul of the Universidade Federal do Rio Grande (CEME-Sul, FURG), Brazil. The studied material was compared with reference bryozoans and types occurring in different bryozoan collections at the Universidade Federal de Pernambuco, Brazil (UFPE); Museu de Zoologia da Universidade Federal da Bahia, Brazil (MZUFBA); Museu de Zoologia da Universidade de São Paulo, Brazil (MZUSP); Smithsonian Institution National Museum of Natural History, USA (NMNH); and the Natural History Museum, UK (NHMUK).

Voucher specimens are deposited at the Coleção Paleontológica do Laboratório de Geologia e Paleontologia, Universidade Federal do Rio Grande (LGP-FURG), Brazil; Museu Oceanográfico Prof. Eliézer de Carvalho Rios, Universidade Federal do Rio Grande (MORG-FURG), Brazil; Coleção de Invertebrados Fósseis do Museu Nacional, Universidade Federal do Rio de Janeiro (MNRJ), Brazil; Coleção Científica de Zoologia-Museu Jóias da Natureza (MJNC), Brazil; Coleção Paleontológica do Laboratório de Estratigrafia e Paleontologia, Universidade Estadual Paulista (LEP-UNESP), Brazil; UFPE, Brazil. Comparative specimens are deposited at NHMUK, London.

\section{Radiocarbon dating}

The radiocarbon measurements were carried out by Accelerator Mass Spectrometry (AMS). Two samples of bryolith colonies (LGP-FURG L-016) were dated: the innermost layer and the external layer. Samples were physically and chemically pretreated at the Radiocarbon Laboratory of the Universidade Federal Fluminense (LAC-UFF; Brazil). The thorough bryolith sampling rules out the exogenous material, since the AMS technique requires ca. $20 \mathrm{mg}$ of sample material. The subsamples were treated with $0.1 \mathrm{M}$ hydrochloric acid in order to remove $50 \%$ of the sample and any possible contamination. Cleaned solid samples were placed in vials with septum lids in order to be pumped out through a needle. The samples were then hydrolysed with $1.0 \mathrm{~mL}$ phosphoric acid and left overnight at room temperature. The tubes were connected to the vacuum line and the gas was purified by means of dry ice/ethanol and liquid nitrogen traps. $\mathrm{CO}_{2}$ samples were then transferred to $9 \mathrm{~mm}$ Pyrex tubes previously prepared with titanium hydride and zinc on the bottom and iron powder inside a 6-mm inner tube. Tubes were sealed with an oxy-acetylene torch and heated to $550^{\circ} \mathrm{C}$ for $7 \mathrm{~h}$ so that $\mathrm{CO}_{2}$ could be reduced to graphite (Macario et al., 2015, 2017; Xu et al., 2007). Graphite samples were pressed in aluminium cathodes and their radiocarbon concentration was measured at the Center for Applied Isotope Studies at the University of Georgia (Cherkinsky et al., 2010).

Radiocarbon ages were calibrated using the Marine13 curve (Reimer et al., 2013) in order to account for the marine reservoir effect (MRE; see, for example, Alves et al., 2018). A value of $17 \pm 56{ }^{14} \mathrm{C}$ years was used for the local offset from the average global marine reservoir (Alves et al., 2015). Apart from the independent individual calibration, the two dated samples can be related by growth order, as the inner sample can be assumed to be older than outer one. This prior knowledge allows for the use of sequential Bayesian modelling (Bronk Ramsey, 2008). Therefore, a simple sequence model was used for calibration of the set of two samples within the OxCal software (Bronk Ramsey, 2008).

\section{X-ray diffraction analyses}

Four samples were collected for mineralogical analyses: two from the outer surface and two from the inner part of two bryoliths (LGP-FURG L-012 and L-016). Approximately $3 \mathrm{~g}$ of powdered samples was submitted for X-ray diffraction (XRD) analysis at CEME-Sul of FURG, using a Brucker AXS D8 Advance model $(\mathrm{Cu} \mathrm{K} \alpha$ radiation, $40 \mathrm{kV}, 40 \mathrm{~mA})$. This was operated in a BraggBrentano $\theta / \theta$ configuration, with the diffraction patterns being collected in a flat geometry with steps of 0.05 degrees and accumulation time of $2.0 \mathrm{~s}$ per step using a PSD detector (Bruker AXS LynexEye model). The XRD data were refined following the Rietveld method with the GSAS-II software (Toby and Von Dreele, 2013).

\section{Results}

\section{Bryolith shapes and composition}

The studied bryoliths show encrusting growth forms (Figure 2(a) $-(\mathrm{g}))$.

The maximum bryolith diameter ranges from 7.5 to $31.0 \mathrm{~cm}$ $($ mean $=19.1 \mathrm{~cm} ; n=36)$ and the minimum diameter ranges from 3 to $18 \mathrm{~cm}$ (mean $=10 \mathrm{~cm} ; n=36)$ with sub-spheroidal, sub-discoidal and sub-ellipsoidal shapes (Figure 2). Four samples consist of sub-spheroidal coral cobbles with a mean maximum diameter of $8.25 \mathrm{~cm}(n=4)$. The coral cobbles are composed of a single zooxanthellate coral species, Astrangia rathbuni Vaughan, 1906.

All collected bryolith specimens are composed mainly by a single encrusting bryozoan species herein identified as a new species: Biflustra holocenica sp. nov. (Figures 5-7). Two subordinate bryozoan taxa were also recognized: Conopeum sp. and Schizoporella sp.

The inner bryolith arrangement is generally asymmetrical, with multilamellar and concentric growths enveloping oyster bivalve shells, sometimes articulated. Shells of Ostrea puelchana d'Orbigny, 1842, were found preserved as the bryolith nucleus (Figure 3(a)-(c), (e)-(g)). In the inner bryolith part, subordinate components (less than 2\%) are represented by the bivalves Sheldonella bisulcata (Lamarck, 1819), Glycymeris longior (Sowerby, 1833), Lithophaga patagonica (d'Orbigny, 1847), Mactraisabelleana (d'Orbigny, 1846), Nucula sp., Ostrea equestris Say, 1834, Phlyctiderma semiaspera (Philippi, 1836), Sphenia fragilis (Adams and Adams, 1854), Plicatula gibbosa (Lamarck, 1801) and by Polychaeta (Serpulidae). No constructional voids (sensu Aguirre et al., 2017) are present.

Bryozoans, corals and bioerosion traces are the dominant components on the outer bryolith surfaces with a relative cover of $54 \%, 10 \%$ and $33 \%$, respectively. Significant differences in relative cover and associated fauna were detected in the sampled bryoliths (ANOVA $F=72.85, p \leqslant 0.0001$; Figure 4(a)). In the outer bryolith surfaces, subordinate components are represented by the bivalves Ostrea equestris and the barnacles Amphibalanus sp. Azooxanthellate coral colonies of $A$. rathbuni were found associated to 25 bryoliths.

Two bioerosion traces were identified within the bryoliths: Gastrochaenolites Leymerie, 1842 and Caulostrepsis Clarke, 1908. The BI is 3. Gastrochaenolites is the most common trace within the samples and occurs randomly spread in all bryoliths. Gastrochaenolites (Figures 2(a), (c)-(g) and 3(a)-(c), (f) and (g)) is a clavate (club-shaped) boring trace. The aperture of the boring is slightly narrower than the main chamber (forming a neck of variable length) and has a circular to ovoid shape with a diameter up to ca. $14.44 \mathrm{~mm}$. The producer of Gastrochaenolites is the bivalve Lithophaga patagonica, preserved within some borings. 


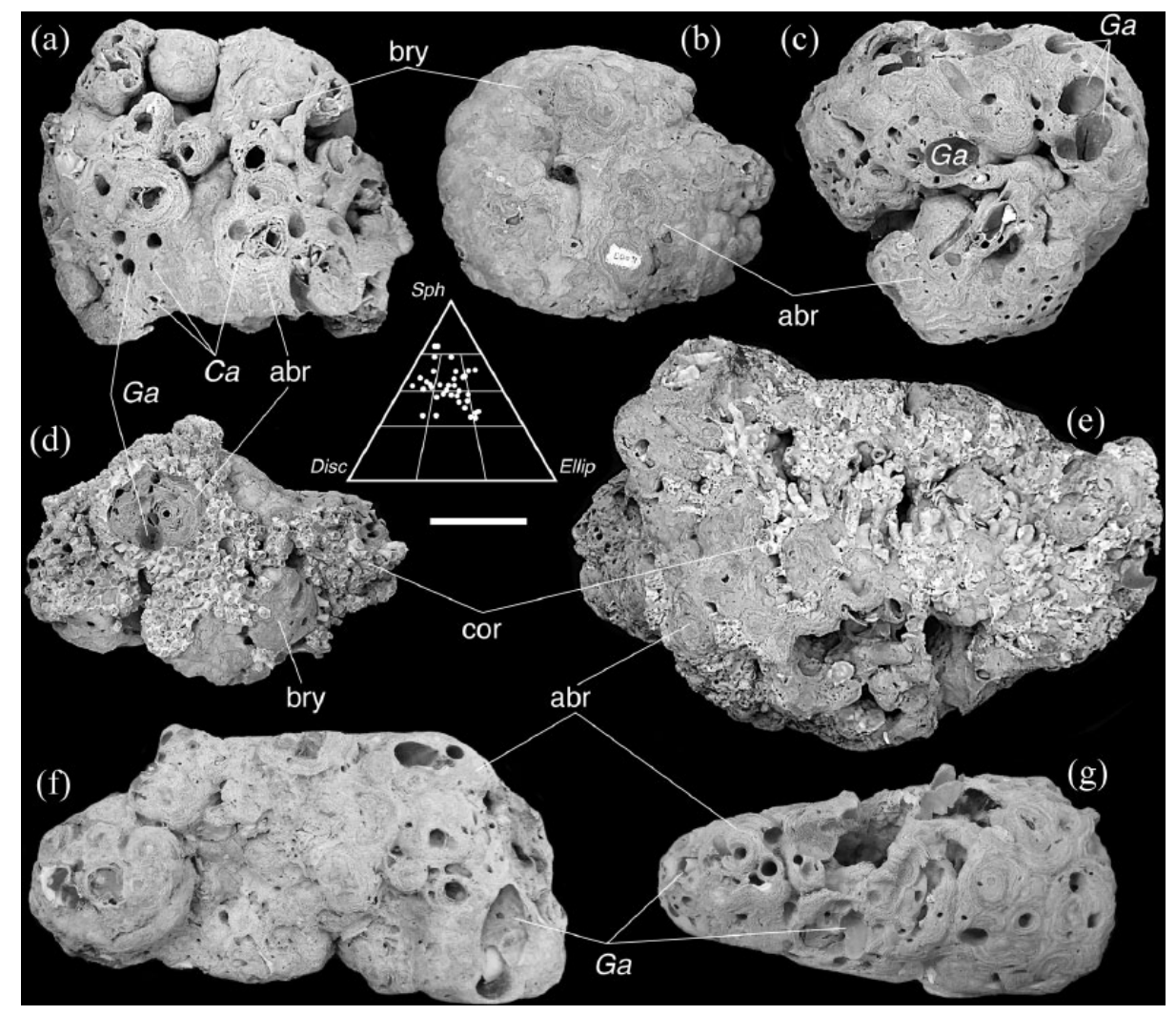

Figure 2. Outer bryolith surfaces showing the encrusting growth forms and the ichnotaxa Caulostrepsis (Ca) and Gastrochaenolites (Ga) along with the identified taphonomic signatures. The bryoliths $(a-e)$ are mainly sub-spheroidal in shape with subordinate sub-ellipsoidal forms (f and g). Note the highly abraded (abr) bryolith outer surfaces. Bry: bryozoans; cor: corals (Astrangia rathbuni); Disc: discoidal; Ellip: ellipsoidal; Sph: spheroidal. Scale bar represents $4 \mathrm{~cm}$.

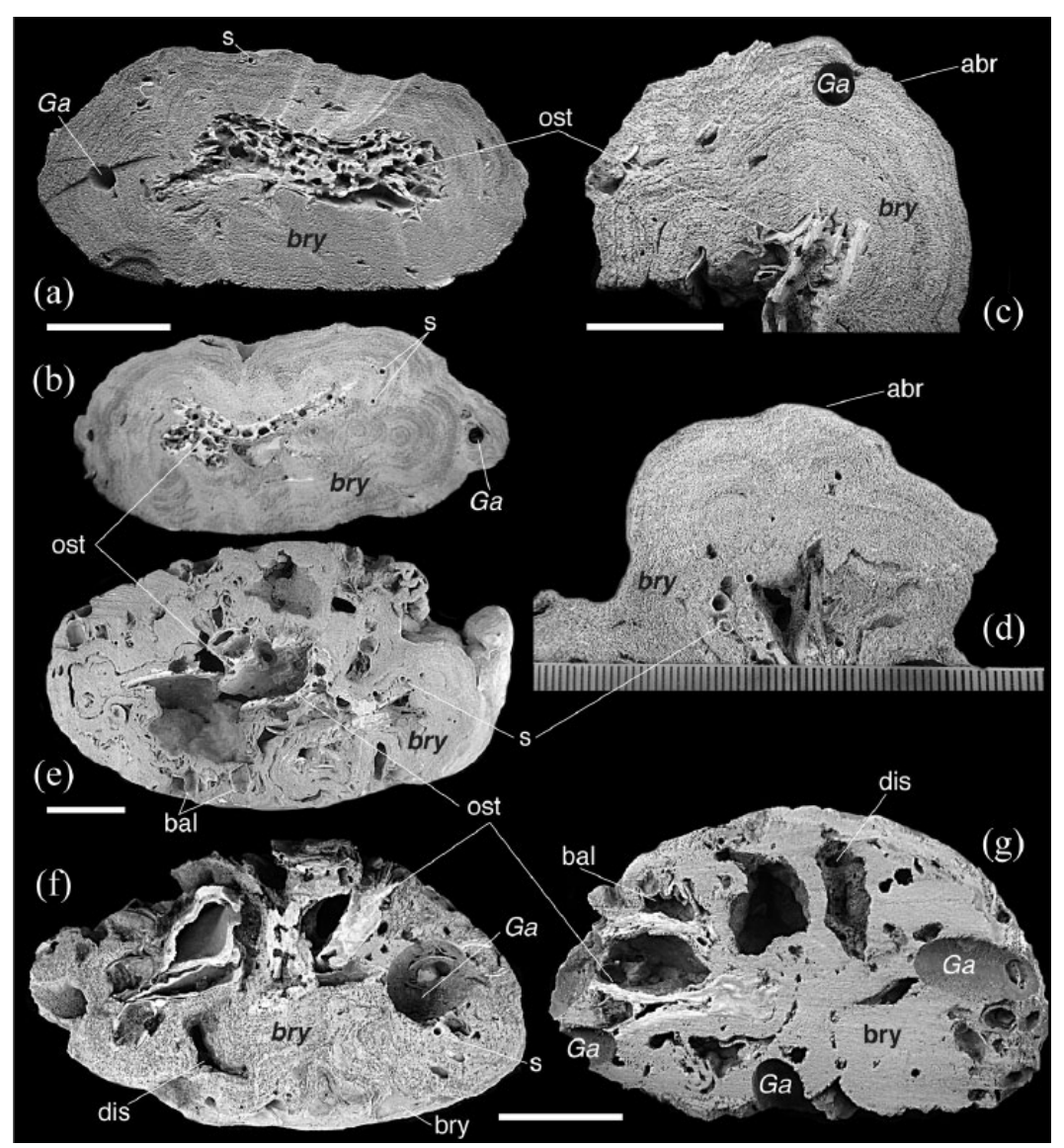

Figure 3. Slab surfaces of studied bryoliths showing the inner arrangement, the building components, the morphologies of common bioerosion traces and taphonomic signatures. Bal: balanids; bry: bryozoans; ost: ostreid; p: polychaetes; Ga: Gastrochaenolites; abr: abrasion; dis: dissolution. Scale bars represent (a and b, d-g) $4 \mathrm{~cm}$, (c) $2 \mathrm{~cm}$. 
Caulostrepsis occurs as cylindrical galleries usually with rectilinear trajectories. The cross-sections are generally sub-elliptical in shape, with rare eight-shaped perimeters (Figure 2(a)). The traces, up to $3 \mathrm{~mm}$ in length, are randomly arranged, roughly equidistant each other, locally perpendicular or oblique to the bryolith surface.

\section{Radiocarbon dating and XRD analyses}

Radiocarbon age estimates for the bryolith's nucleus and outer surface are statistically similar (Table 1) preventing the estimation of longevity or growth rates. Considering the growth sequence, the calibrated and modelled dates (Figure 4(b)) provide similar results with up to 300 years range at $7910-7600 \mathrm{cal}$. yr BP $(2 \sigma)$

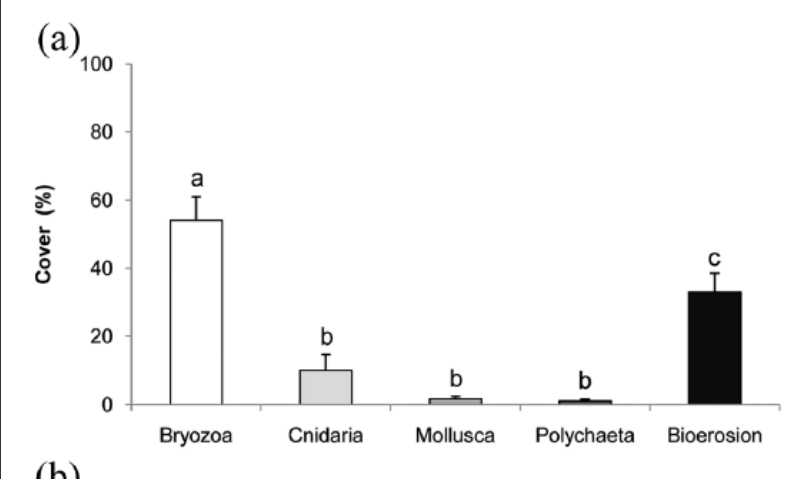

(b)

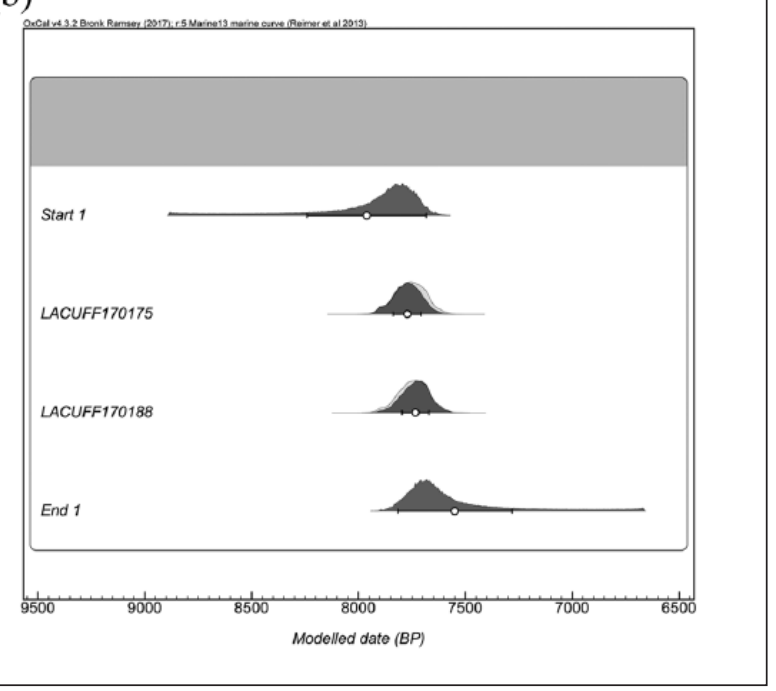

Figure 4. (a) Relative cover (\%, mean $\pm S E$ ) of benthic organisms and bioerosion traces on bryoliths surfaces sampled. Different letters above bars indicate significant differences among means detected by Tukey's test $(p<0.05)$. (b) The modelled datings of the sample LGP-FURG L-0I6.
The stable isotope for the inner bryolith part reflects the isotopic composition of dissolved inorganic carbon (DIC) in the marine water.

Table 2 shows the results of XRD of the inner part and outer surface of the two analysed bryoliths (LGP-FURG L-012 and L-016).

$\mathrm{Mg}$-calcite predominates in all layers. From the XRD, it was possible to determine the $\mathrm{Mg}$ content as $10 \mathrm{~mol} \% \mathrm{MgCO}_{3}$, classified as high magnesium calcite (HMC). Aragonite and quartz are also present.

\section{Systematics}

Order: Cheilostomata Busk, 1852

Family: Membraniporidae Busk, 1852

Genus: Biflustra d'Orbigny, 1852

Species: Biflustra holocenica Vieira, Spotorno-Oliveira and Tâmega sp. nov. (Figures 5-7) urn:Isid:zoobank.org:act:BD2D25FC-78EA4BAB-9625-6A6E962F83B8.

Conopeum commensale: Barbosa, 1967; Non Conopeum commensale Kirkpatrick and Metzelaar, 1922

Etymology: From the epoch Holocene, with reference to the dating results of the holotype.

Holotype: LGP-FURGL-007 Hermenegildo beach to $45 \mathrm{~km}$ of Concheiros do Albardão beach. The holotype is a colony presumably multilayered and with a circumrotatory growth forming a sub-spheroidal bryolith $(15 \mathrm{~cm} \times 12 \mathrm{~cm} \times 7 \mathrm{~cm})$. Outer surfaces well preserved with occurrence of bioerosion traces less than 5\%. (Figure 5(a)). The inner bryolith arrangement is mainly asymmetrical, with multilamellar and circumrotatory growth of colonies that envelop the shell fragment, which remains preserved as the bryolith nucleus (Figure 5(b)).

Paratypes: MNRJ-4887-I (locality information as above; M.M. Barbosa col. (The paratype is a colony presumably multilayered and with a circumrotatory growth forming a sub-spheroidal bryolith (axis dimensions $12 \mathrm{~cm} \times 11 \mathrm{~cm} \times 7 \mathrm{~cm}$ ), studied and reported by Barbosa (1967), illustrated in Figures 5(c) and (d))); LGP-FURG L-016 (locality information as above; L.R. Oliveira col.); UFPE 191 (off Hermenegildo beach to $45 \mathrm{~km}$ of Concheiros do Albardão beach, locality information as above; L.R. Oliveira col.); LEP-Co6-11-1 (Concheiros do Albardão beach, 3330'06.70" S, 5303'01.26" W; 19 December 2011; F.S. Buchmann col.); LEP-Co9-13-1 (Concheiros do Albardão

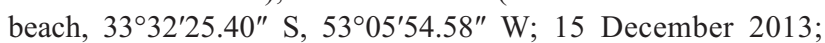
F.S. Buchmann col.); MJNCA04 (locality information as for holotype; F.S. Buchmann col.); LEP-Co9-15-1 (Concheiros do Albardão beach, $33^{\circ} 32^{\prime} 25.40^{\prime \prime} \mathrm{S}, 53^{\circ} 05^{\prime} 54.58^{\prime \prime} \mathrm{W} ; 18$ January 2015; F.S. Buchmann col.); LEP-LR-15-5-1 (Concheiros do Albardão beach, 3330'54.95" S, 5303'57.60" W; 4 May 2015; F.S. Buchmann col.); LEP-LR-17-5-1 (Concheiros do Albardão beach, 33³0'54.95" S, 5303'57.60" W; 20 May 2017; F.S. Buchmann col.); LEP-LR-17-5-2 (Concheiros do Albardão beach,

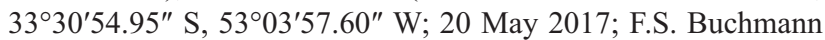
col.); LEP-N17a-80-1 (Farol da Conceição, São José do Norte,

Table I. Sizes and analytical data for conventional radiocarbon calibrated and modelled age estimates $(95.4 \%)$ for the nucleus and outer bryolith sample.

\begin{tabular}{|c|c|c|c|c|c|c|}
\hline \multirow{2}{*}{$\begin{array}{l}\text { Bryolith specimen } \\
\text { LGP-FURG L-016 }\end{array}$} & \multicolumn{6}{|c|}{ Axes sizes $(\mathrm{cm})$} \\
\hline & Long & Interm. & Short & $\begin{array}{l}{ }^{14} \mathrm{C} \text { age } \\
\left({ }^{14} \mathrm{C} \text { yr BP }\right)\end{array}$ & $\begin{array}{l}\text { Modelled age } \\
\text { (cal.yr BP) }\end{array}$ & $\begin{array}{l}\text { Cal. age (cal. yr BP) } \\
(2 \sigma)\end{array}$ \\
\hline $\begin{array}{l}\text { LACUFFI } 70 I 75 \\
\text { (nucleus) }\end{array}$ & 26 & 19 & 15 & $7311 \pm 31$ & $7910-7650$ & $7910-7620$ \\
\hline $\begin{array}{l}\text { LACUFFI70I88 } \\
\text { (outer surface) }\end{array}$ & & & & $7295 \pm 30$ & $7870-7600$ & $7890-7600$ \\
\hline
\end{tabular}

Interm: intermediate; cal: calibrated. 
Rio Grande do Sul, Brazil; 3143'48.29" S, 51²8'53.79" W; 12 April 1999; F.S. Buchmann col.); LGP-FURG L-001 to 006; 008 to 015 ; 017 to 028 (locality information as for holotype L.R. Oliveira col.); eight additional specimens not catalogued/deposited (locality information as for holotype L.R. Oliveira col.) and MORG 52680 (40 km north of Hermenegildo beach; 33⒉ $8^{\prime} 4^{\prime \prime} \mathrm{S}$, $53^{\circ} 0^{\prime 2} 6^{\prime \prime}$ W; 26 September 2017; P.S. Oliveira and F.T.S. Tâmega col.; on living gastropod).

Additionally analysed specimens: Non-type specimens of $\mathrm{Bi}$ flustra holocenica sp. nov.: Comparative species: NHMUK 1892.9.6.1, Membranipora denticulata, holotype, G. Busk det. 1856, Mazatlan, Gulf of California; NHMUK 1922.9.9.9, Conopeum commensale, type, Kirkpatrick and Metzelaar det. 1922, Cablo Blanco, West Africa; UFBA 1258, Biflustra arborescens (Canu and Bassler), Almeida et al. (2017), Bahia, Brazil.

Type locality: Hermenegildo beach to $45 \mathrm{~km}$ of Concheiros do Albardão beach, as above (Figure 1).

Age: Holocene

Description: Colony encrusting multiserial, unilaminar to plurilaminar, massive (Figure 6(a)). Autozooids almost rectangular with well-calcified lateral walls, slightly wider at their distal third, with straight to slightly convex proximal and rounded distal end (Figures 6(a) and (b)). Zooids 0.432-0.525 mm (0.456 \pm $0.022 \mathrm{~mm} ; n=20)$ long and $0.251-0.294 \mathrm{~mm}(0.275 \pm 0.011$ $\mathrm{mm} ; n=20$ ) wide, limited by distinct grooves. Gymnocyst ab-

Table 2. Mineral composition of the outer surface (OS) and the nucleus $(\mathrm{N})$ of analysed bryoliths by weight (\%).

\begin{tabular}{lllll}
\hline Bryolith specimen & OS/N & Mg-calcite (\%) & Aragonite (\%) & Quartz (\%) \\
\hline LGP-FURG L-016 & IOS & 87.7 & 10.2 & 2.1 \\
& 2N & 86.6 & 8.3 & 5.1 \\
LGP-FURG L-012 & 3 OS & 89.8 & 8.9 & 1.3 \\
& $4 N$ & 87.8 & 10.6 & 1.6 \\
\hline
\end{tabular}

sent. Cryptocyst surrounding the entire opesia, wider proximally than laterally, $0.080-0.150 \mathrm{~mm}(0.114 \pm 0.008 \mathrm{~mm} ; n=20)$ long well calcified, beaded, with median portion slightly sloping down toward the opesia (Figure 6(b)). Cryptocystal denticles absent. Opesia almost oval, 0.276-0.330 mm (0.318 \pm $0.014 \mathrm{~mm} ; n=20)$ long and $0.169-0.202 \mathrm{~mm}(0.186 \pm 0.008$ $\mathrm{mm} ; n=20$ ) wide, occupying about two-thirds of the zooid length. Kenozooids (Figure 6(c)) rare, intercalated among autozooids, variable in size and shape, about $0.081-0.158 \mathrm{~mm}$ $(0.120 \pm 0.028 \mathrm{~mm} ; n=9)$ long and $0.066-0.197 \mathrm{~mm}(0.115$ $\pm 0.048 \mathrm{~mm} ; n=9$ ) wide, triangular to irregularly polygonal, smaller than autozooids; beaded cryptocyst equally developed around the suborbicular opesia. Distal transverse wall with two multiporous mural septula near the basal wall, each one with three to six perforations in the septulum. Lateral transverse walls with three multiporous mural septula, each with three to seven perforations in the septulum (Figure 6(d)). Basal and vertical walls with spinules (Figure 6(d)); one hook-shaped spinule seen in each lateral wall, placed at proximal third of zooidal length near the basal wall (Figure 6(e)).

Systematic remarks: Despite controversies in usage of Biflustra d'Orbigny, 1852 and Acanthodesia d'Orbigny, 1852 for some Membraniporidae species (Almeida et al., 2017; Cook et al., 2018; Di Martino and Taylor, 2018; Taylor and Tan, 2015), here we follow Almeida et al. (2017) and Cook et al. (2018) which rejected Acanthodesia as a valid genus of species clearly classified, at least at zooidal morphological level, as Biflustra. The new species is assigned to Biflustra.

Among the Biflustra species, spinules at basal and vertical walls are known only in Biflustra denticulata (Busk, 1856) and Biflustra paulensis (Almeida et al., 2017; Marcus, 1937). Biflustra denticulata (Figure 8(a)), however, differs in having cryptocystal denticles projecting into the opesia, and in having the proximal cryptocyst narrower than that of Biflustra holocenica sp. nov. Biflustra paulensis has gymnocystal tubercles (absent in

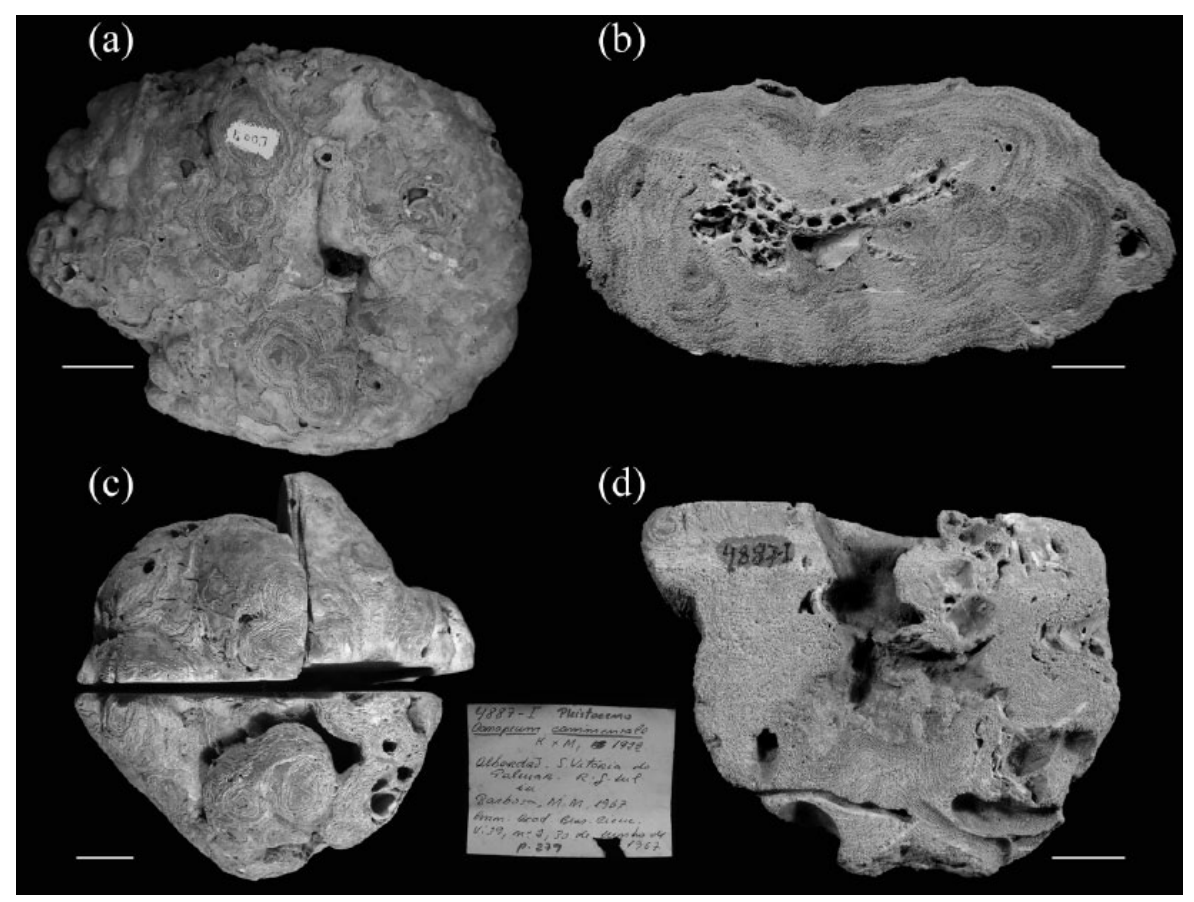

Figure 5. Bryoliths mainly formed by Biflustra holocenica sp. nov. (a) The outer surfaces of bryolith LGP-FURGL-007 with holotype on surface. (b) Bryolith LGP-FURGL-007 showing the inner asymmetrical arrangement, with multilamellar and circumrotatory growth colonies that envelop the shell fragment. (c) Bryolith (MNRJ-4887-I) formed by bryozoan previously assigned to Conopeum commensale by Barbosa (1967) and here reassigned to the new species. (d) The inner arrangement growth colonies (MNRJ-4887-I). Scale bar represents $2 \mathrm{~cm}$. 

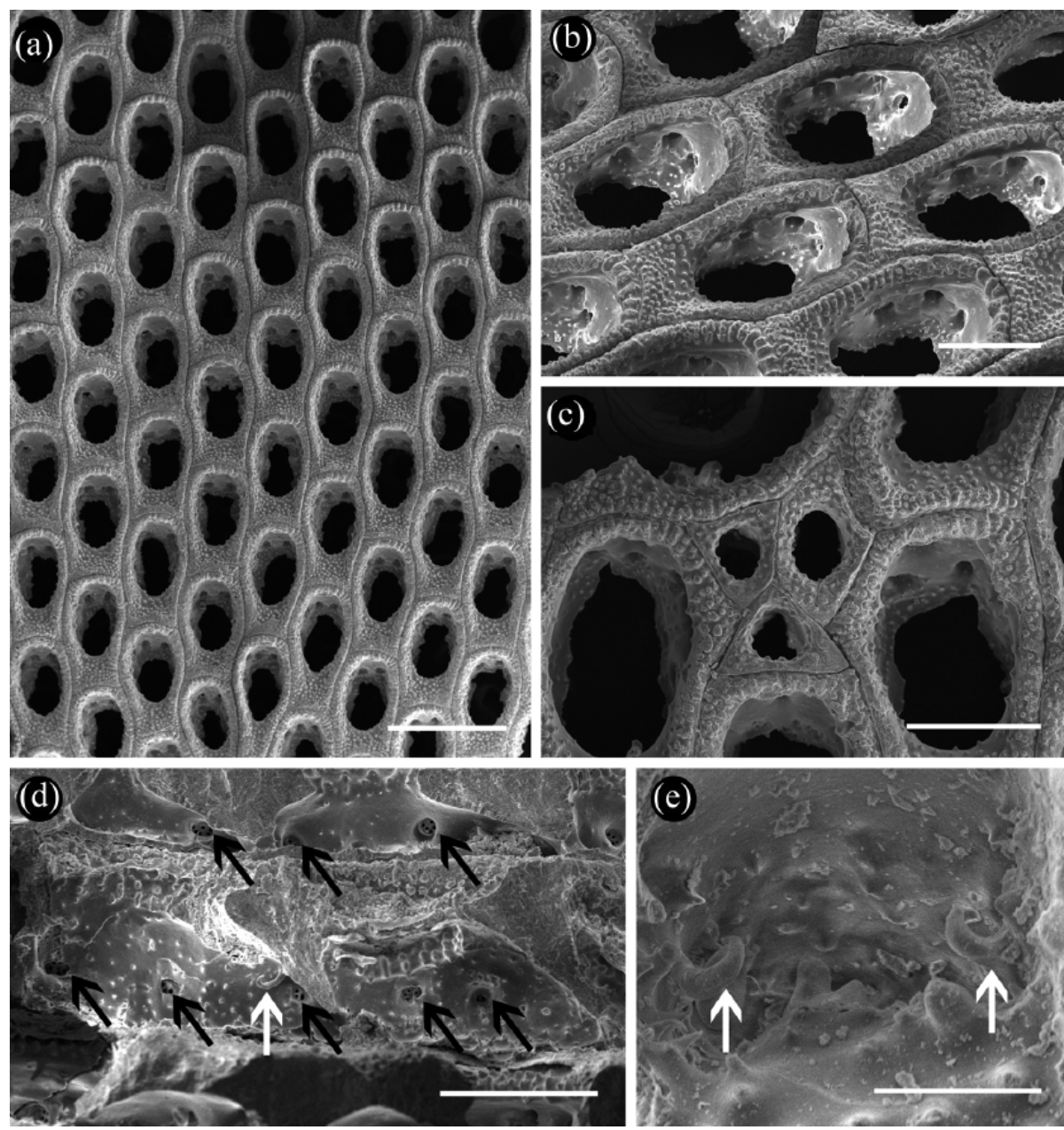

Figure 6. SEM photos of holotype specimens of Biflustra holocenica sp. nov. (on the surface of bryolith LGP-FURG L-007): (a) Detail of the frontal surface of the colony; (b) close-up of the autozooids, showing the lateral and distal pore plates; (c) close-up of three kenozooids; (d) internal lateral walls of the autozooids, showing the multiporous mural septula (black arrows) and internal spinules (white arrow); and (e) internal view of one autozooid, showing paired hook-shaped spinules in the lateral zooidal walls. Scale bar represents (a) $500 \mu \mathrm{m}$, (b-d) $200 \mu \mathrm{m}$ and (e) $50 \mu \mathrm{m}$.
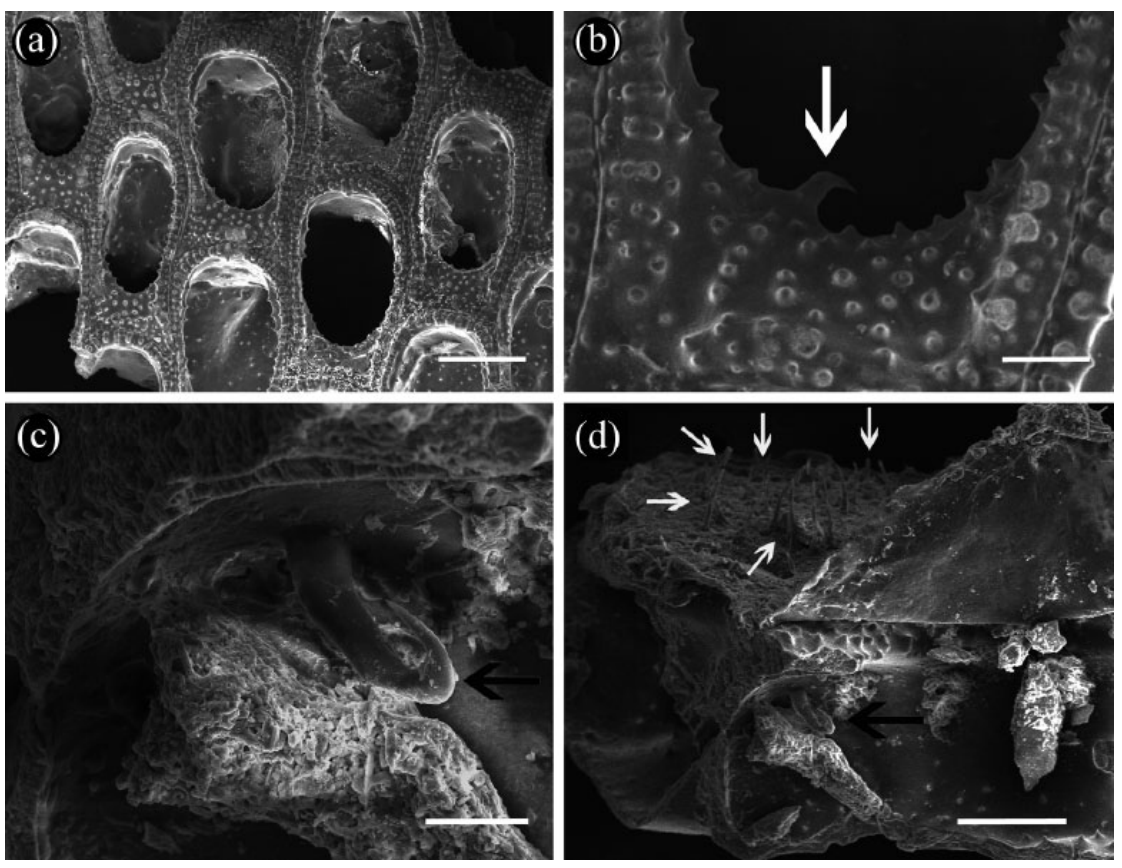

Figure 7. SEM photos of living specimens of Biflustra holocenica sp. nov (MORG 52680): (a) Detail of the skeletal autozooids; (b) close-up of the proximal cryptocyst, showing the proximal denticle (white arrow); (c) internal lateral walls of the autozooids, showing the internal hook-shaped spinule (black arrow); and (d) lateral view of the autozooids, showing frontal membrane with chitinous spinules (white arrows) and internal hook-shaped spinule in the lateral zooidal walls (black arrow). Scale bar represents (a) $200 \mu \mathrm{m}$, (b) $50 \mu \mathrm{m}$, (c) $25 \mu \mathrm{m}$ and (d) $100 \mu \mathrm{m}$. 

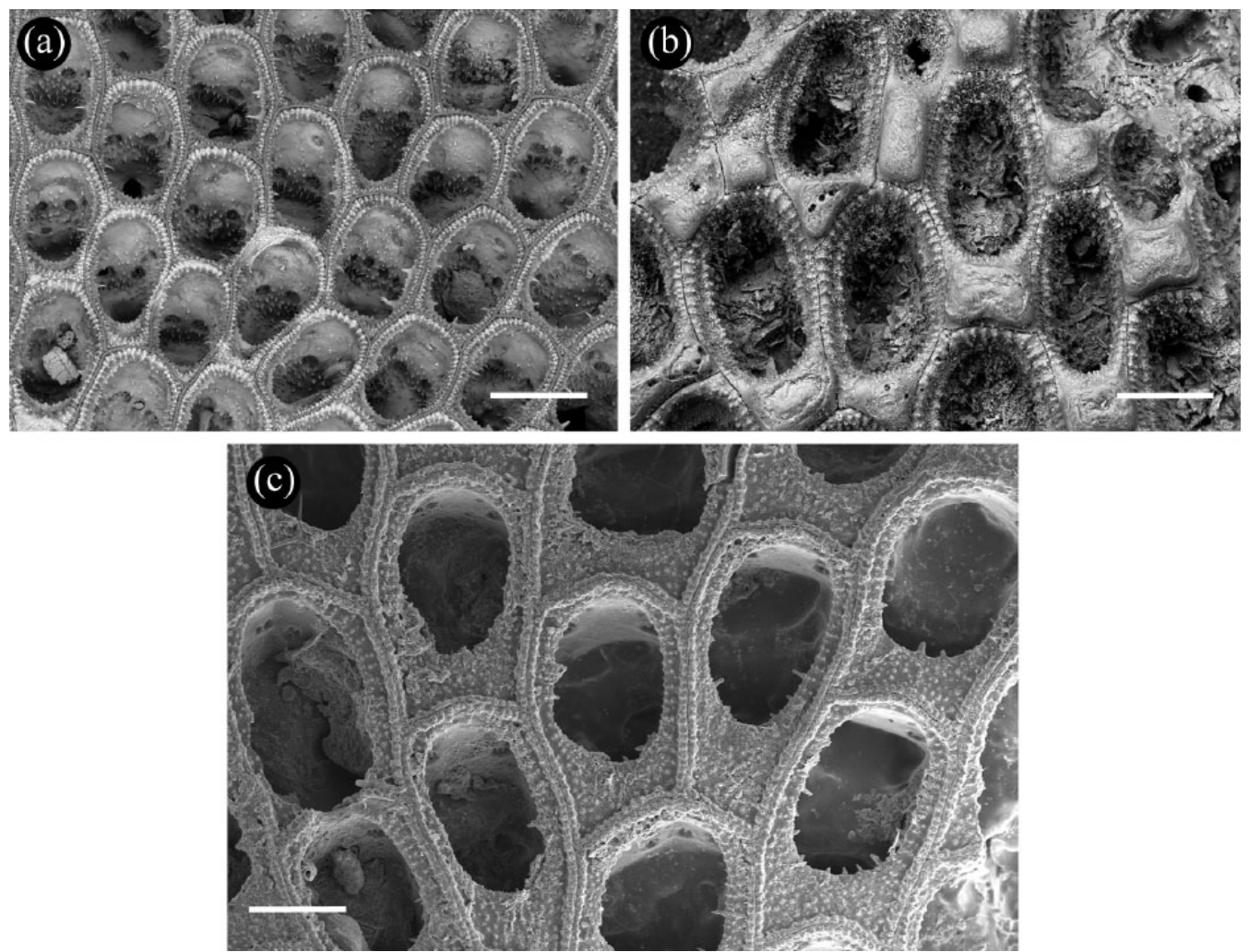

Figure 8. SEM photos of three morphologically related species: (a) Holotype specimen of Biflustra denticulata (Busk, I856) (NHMUK 1892.9.6. I) from Mazatlan, Gulf of California; (b) part of the type specimen of Biflustra commensale (Kirkpatrick and Metzelaar, 1922) (NHMUK 1922.9.9.9) from Cabo Blanco,West Africa; (c) specimen of Biflustra arborescens (Canu and Bassler) (UFBA I258) from Bahia, Brazil. Scale bar represents $200 \mu \mathrm{m}$.

Biflustra holocenica sp. nov.) and an opesia occupying threequarters of the zooidal length (opesia occupies no more than twothirds of the zooidal length in Biflustra holocenica sp. nov.). The well-known Acanthodesia commensale (Figure 8(b); Klicpera et al., 2013) forming bryoliths, also referred to as Biflustra commensale (Almeida et al., 2017), has large paired gymnocystal tubercles that may be coalescent, and the autozooids are outlined by a brown line, characteristics that are not seen in Biflustra holocenica sp. nov. In addition, the internal hook-shaped spinules, characteristic of Biflustra holocenica sp. nov., are absent in Biflustra commensale.

Some Recent colonies of Biflustra collected on living gastropods from $40 \mathrm{~km}$ north off Hermenegildo beach (MORG 52680) have a skeletal morphology (Figure 7(a)-(d)) similar to the studied Holocene holotype and paratypes. Despite the presence of a single minute proximal denticle projecting into the opesia (Figure 7(b)) only in the recent colonies (lost in the studied fossil material during the taphonomic processes), we consider both fossil and living specimens to be conspecific. In addition, organic parts of living colonies were examined, revealing the presence of external chitinous spinules on the frontal membrane of autozooids (Figure 7(d)), a feature not seen in the fossil specimens.

A frontal membrane with spinules is also described in Biflustra arborescens (Canu and Bassler, 1928) recorded from Brazil (Almeida et al., 2017). Biflustra holocenica sp. nov. and Biflustra arborescens share other similarities in skeletal morphology, including autozooidal size, absence of gymnocyst, cryptocyst occupying one-third of zooidal length and morphology of multiporous mural septula in vertical walls. Biflustra holocenica sp. nov. differs from Biflustra arborescens, in having basal and vertical walls with spinules, and paired hook-shaped spinules at proximal third of lateral vertical walls (absent in Biflustra arborescens). The single minute proximal denticle projecting into the opesia is rarely present in Biflustra holocenica sp. nov., while these denticles may be numerous in Biflustra arborescens (Figure 8(c)).

In total, 32 Biflustra species are registered worldwide (Bock and Gordon, 2018), with 8 species distributed along the Brazilian coast, from Alagoas to Santa Catarina State. These species may be found from shallow waters to $100 \mathrm{~m}$ depth, being abundant between 5 and $30 \mathrm{~m}$ water depth (Almeida et al., 2017; Vieira et al., 2008, 2016). Biflustra is recorded here for the first time in the RS as a fossil specimen (ca. $8000 \mathrm{cal}$. yr BP forming bryoliths). Present-day Biflustra holocenica sp. nov. are found growing as sheet-like colonies on the external surface of living gastropod shells, while one colony was found on a beached styrofoam buoy.

\section{Discussion}

The studied Holocene bryoliths were found in foredunes. Their occurrence in a subaerial setting suggests that (1) the bryoliths were redeposited according to the relative sea-level (RSL) changes; (2) they formed on a coarse, soft, substrate; and (3) they were resedimented onto foredunes during the Holocene coastal dynamics that affected the RSCP area. The following discussion addresses details of the bryolith's radiocarbon datings and compositional and morphological features to assess the RSCP palaeoenvironmental dynamics.

\section{The radiocarbon dating}

The radiocarbon ages are affected by some factors such as radiocarbon MRE, incorporation of dead carbon from limestone, possible aggregation of boring bivalves and recrystallization of aragonite and $\mathrm{HMC}$. MRE contributes to the depletion of ${ }^{14} \mathrm{C}$ concentration in marine samples leading to apparent old ages (Alves et al., 2018). 

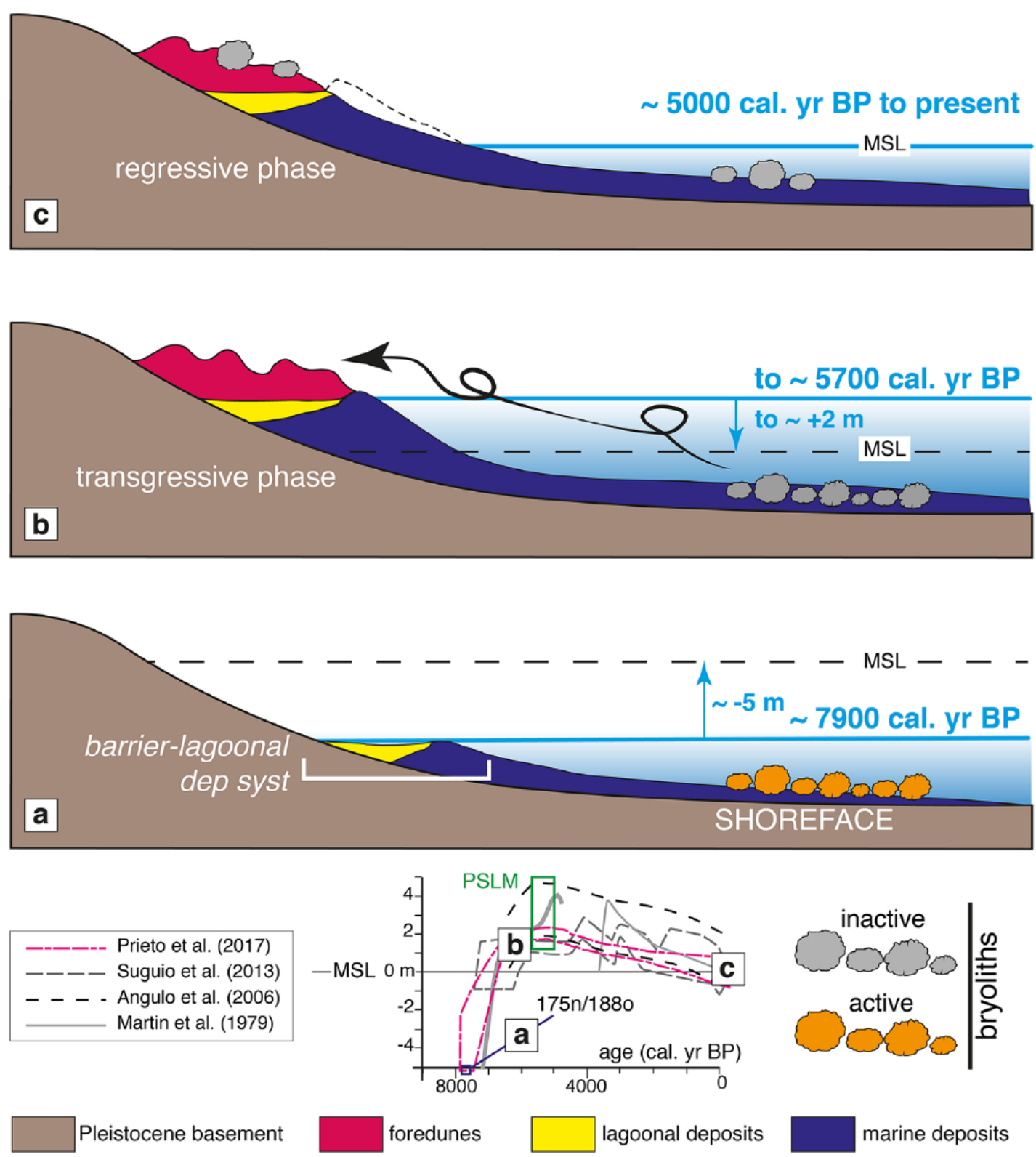

Figure 9. Reconstruction of the Holocene palaeoenvironmental dynamics for the studied bryoliths in the Hermenegildo and Concheiros beaches, southern Brazil. The arrows refer to the trend of the sea level (fall or rise). The sample ages are based on radiocarbon dating (this study). The two dated bryolith nuclei (175//88) plotted with Holocene sea-level curves of Martin et al. (1979), Angulo et al. (2006), Suguio et al. (20I3) and Prieto et al. (20I7). (a) At ca. 7900 cal. yr BP, the studied bryoliths formed on coarse soft substrate, in the shoreface part of a barrier-lagoon depositional system (Lima et al., 2013). (b) Until the PSLM (ca. $5700 \mathrm{cal}$. yr BP), the bryoliths were resedimented onshore onto foreshore and foredunes. (c) After the end of the PSLM to the present, during a slow sea-level fall, the bryoliths were preserved in the presentday beach foredunes. MSL: mean sea level; dep syst: depositional system; PSLM: postglacial sea-level maximum (5I00-5700 cal. yr BP; Angulo et al., 2006). Not to scale.

Such effect was considered through calibration with the marine curve and the use of local reservoir offset estimates. Aggregation of younger bivalve shells that would result in underestimated ages is ruled out as only the bryolith layers were sampled. Incorporation of dead carbon fraction within radiocarbon-dated bryoliths would also result in an overestimated age of the bryoliths (e.g. Wiener, 2012). However, there is no evidence of limestone deposits in this region. Finally, aragonite and HMC can dissolve and recrystallize into low magnesium calcite (LMC). This process could facilitate the exchange of carbon with the environment, increasing the chances of younger carbon being incorporated into the lattice. As the XRD results show a composition of HMC and aragonite, recrystallization is unlikely to have occurred.

Assuming that no exogenous carbon was incorporated to the sample, the calibrated radiocarbon ages of the LGP-FURG L-016 bryozoan sample are ca. 7910 to $7600 \mathrm{cal}$. yr BP (Figure 9).

\section{Palaeoecology of the Holocene bryoliths}

At the estimated age of the studied bryoliths, the sea level was -5 $\mathrm{m}$ below the present sea level (e.g. Prieto et al., 2017). The RSCP has some particular characteristics concerning the shoreface bathymetry, and the inner continental shelf is a result of transgressive and regressive events caused by glacial and postglacial sea-level changes (Calliari and Klein, 2011). As the shoreface of the studied area is wide and shallow with seaward limit at 10-15 $m$ depth (Toldo et al., 2006), at the time of the bryolith growing age, the shoreface should have been about $20 \mathrm{~m}$ below the present sea level.

The foredunes formed at ca. 5700 cal. yr BP (Figure 9(b)) during the postglacial sea-level maximum (PSLM) when the sea level was ca. $2 \mathrm{~m}$ above the present sea level (e.g. Angulo et al., 2006; Prieto et al., 2017). This time slice was ca. 2000 years after the bryolith formation. The bryoliths should not, therefore, be 
deeply burrowed under the substrate as they would be easily reexhumed. Therefore, if the bryoliths formed in the shoreface setting, they should have undergone a resedimentation ranging in elevation from ca. 17 to $22 \mathrm{~m}$, that took them from their factory setting onto the subaerial one.

The likelihood of a shallow burial is supported by very low sedimentation rate of the area as confirmed by moderate bioerosion (e.g. Bassi et al., 2013), three orders of magnitude difference in the shell ages of bivalve shells (Ritter et al., 2017) and the presence of the ichnotaxa Gastrochaenolites (Bromley and Asgaard, 1993), most common and produced by mytilid bivalves, and Caulostrepsis, attributed to the boring spionid polychaete Polydora (Domènech et al., 2008), eucinids (Martinell and Domènech, 2009) and cirratulids (Bromley and D'Alessandro, 1983; Taylor and Wilson, 2003). It also demonstrates that these bryoliths, as other macroids, are prone to span at least some time at the sediment-water interface before the burial due to their relatively high durability. In the studied area, the bryoliths act as spotted hard substrates because locally they are supporting a high biodiversity, being an important colonization surface for sclerobionts together with molluscs (Agostini et al., 2017).

According to Kidwell and Gyllenhaal (1998), a balance of low sedimentation rate (to avoid burial), intermittent high energy (to overturn episodically) and appreciable growth rate of the encrusting organisms (Hottinger, 1983) is required for macroids development. Fast growing organisms, like membraniporid bryozoans, are able to settle on any consolidated fragment or on bioclasts (as the oyster Ostrea puelchana) and increase rapidly in size, quickly covering the colonized substrate.

A relatively shallow setting is also argued by the morphological characteristics of the nodules and the associated identified biota.

Although no shape-water energy relationship has been so far assessed for modern and fossil bryoliths, the shape of rhodoliths is commonly used as an indicator of turbulence and how often they are overturned (e.g. Aguirre et al., 2017). Sub-spheroidal shapes, along with common sub-ellipsoidal and rare spheroidal ones, as seen in Figure 2, are indicative of easy roll on the mobile substrate. Waves and tidal currents are the most common agents for such movements, but bioturbation may also play a role (e.g. Aguirre et al., 2017; Bassi et al., 2006; Foster, 2001; Marrack, 1999). All such agents may have been active in the Holocene RSCP shallow shoreface setting. The dominating encrusting growth form suggests a constant water motion induced by wave/current bed setting as concluded for rhodoliths (e.g. Marrack, 1999).

In the studied materials, the nucleus consists of an articulated specimen of the oyster Ostrea puelchana. This oyster shows a wide depth distribution from 10 to $100 \mathrm{~m}$ water depth (Rios, 2009; Romero et al., 2013).

In the studied bryoliths, the identified coral Astrangia rathbuni is very common. The present-day setting for Astrangia rathbuni is related to biogenic substrates from inner to mid-continental shelf. Astrangia rathbuni is restricted to shallow water (18-81 m) being most common at $48 \mathrm{~m}$ depth (Kitahara et al., 2009). Considering that the studied bryoliths show almost no important breakages (e.g. Figures 2(a)-(g), 3(a)-(d), 5(a) and (b)), high abrasion (Figures 2(a)-(g), 3(c) and (d)) or size selection (Figure 2), this indicates that the bryoliths were most probably re-exhumed and transported from a shallow setting, which is in good agreement with the shallowest bathymetric distributions of Ostrea puelchana and Astrangia rathbuni. Modern bryoliths are found in subtidal marine environments at a depth of $7 \mathrm{~m}$ outside Punta Chivato, Gulf of California (James et al., 2006).

Biflustra holocenica sp. nov. has a bi-mineralic skeleton made up of HMC and aragonite. This composition has been so far demonstrated for a minority of bryozoan species, whereas most of them have LMC (Kuklinski and Taylor, 2009; Smith et al., 2006;
Taylor et al., 2009, 2015). The colonies can therefore be attributed to the major groups of Cheilostomes (Malacostegina, Flustrina, Umbonulomorpha and Lepraliomorpha) with aragonite skeletons (Taylor et al., 2015).

Chave (1954) showed a positive correlation between the magnesium content of the $\mathrm{Mg}$-calcite skeletons and the temperature of the water in which the organism lived, with higher values of $\mathrm{Mg}$ in warmer water. However, Smith et al. (1998) found no consistent mineral trend with temperature for Bryozoa around New Zealand, and Arctic species show no correlation with temperature (Kuklinski and Taylor, 2009). Data compilations (Kuklinski and Taylor, 2009; Taylor et al., 2015) show that a higher proportion of Bryozoa have higher Mg contents in lower latitudes; however, the absence of correlation with temperature at specific locations such as New Zealand and the Arctic suggests caution must be exercised when trying to determine palaeotemperature conditions based on just the $\mathrm{Mg}$ content from one sample set. The $10 \mathrm{~mol} \% \mathrm{MgCO}_{3}$ for our study bryoliths is consistent with the range of values found for Bryozoans from mid- and low-latitude locations (Taylor et al., 2015).

The climatic scenario for the marine environment along the southwestern Atlantic during the mid-Holocene indicates the sea surface temperature was slightly warmer, between ca. $32^{\circ} \mathrm{S}$ and $47^{\circ} \mathrm{S}$ (Aguirre et al., 2009), following a latitudinal decrease toward higher latitudes. This means that temperatures were warmer than those recorded at present at the same latitudes, as also suggested by Martínez et al. $(2001,2013)$ for the Uruguayan coast, allowing the macroids formation. Thus, it may be that our Bryozoan $10 \mathrm{~mol} \% \mathrm{MgCO}_{3}$ is reflective of higher temperatures at that time. However, this proposition cannot be confirmed without either experimental work or sampling along a temperature gradient, to determine the response of the $\mathrm{Mg}$ content to changes in temperature for this species to give our results context.

\section{Palaeoenvironmental dynamics}

The Hermenegildo sedimentary successions represent a barrierlagoon depositional system formed about 9800 years ago during the sea-level transgression (Buchmann et al., 1998; Lima et al., 2013). The RSL had overtaken present MSL by ca. 7000 cal. yr BP (Angulo et al., 2006; Prieto et al., 2017; Figure 9).

At ca. 6700 cal. yr BP, the lagoonal floor sedimentation was active with a permanent connection to the ocean in the form of single inlets (Buchmann et al., 1998; Lima et al., 2013). The balance profile of the beach changed, making available a large amount of sedimentary material, from the reworking of the Pleistocene beaches and terraces.

The subsequent high stand occurred between 5800 and 5200 cal. yr BP (PSLM) reaching as high as $+2 \mathrm{~m}$ above present MSL. In the studied area, this RSL rise period is characterized by transgressive foredunes moving into the lagoon. The dune transgression has been occurring at the same time as the erosion of the lagoonal barrier (Buchmann et al., 1998; Lima et al., 2013). During this RSL rise, storm surges resedimented the studied bryoliths from the shoreface setting where they formed, onto the foreshore and foredunes (Figure 9(b)). The erosive processes are attributed to storm surge and concentration of wave on the beach caused by the presence of lithified structures in the backshore and to negative sediment budget (Calliari et al., 1998; Dillenburg et al., 2004).

If bryoliths had been transported with storms from offshore, they would have been piled up in a wedge-shaped abutment against the foredune face (e.g. Johnson et al., 2012).

Resedimentation of large nodules has been interpreted for offshore and inshore rhodolith deposits (e.g. Bassi et al., 2010; Checconi et al., 2010; Johnson et al., 2012). In the studied area, resedimentation is likely to be brought about by combinations of winds and storm waves as well as the higher energy of longshore 
currents whose present-day southerly waves are dominant $30 \%$ of the time (Lima et al., 2001).

At the maximum level of PSLM, the transgression of the barrier during the sea-level rise was complete (Lima et al., 2013; Figure 9(b)).

At Hermenegildo and Concheiros do Albardão areas, after the end of the PSLM to the present, during a slow sea-level fall of approximately $2 \mathrm{~m}$ (Figure 9(c)), the progradation occurred in coastal embayments due to the onshore transfer of sands from the shoreface of RS (Dillenburg et al., 2000). It was in the foredunes formed during this time that the bryoliths were finally buried.

\section{Concluding remarks}

A new species of bryozoan has been described herein for the Southern Brazilian shelf, Biflustra holocenica Vieira, SpotornoOliveira and Tâmega sp. nov. This fossil bryolith occurring in the Hermenegildo and Concheiros foredunes represents a witness of a Holocene marine shoreface ecosystem that probably disappeared ca. 7600 years ago. These bryoliths are made up of the dominant component Biflustra holocenica still occurring in this area. However, although small colonies found living on shells of gastropods are still present in the area, they are not able to form bryoliths as described in this study.

Bioerosion traces of two kinds were identified within the bryoliths: Gastrochaenolites and Caulostrepsis. This demonstrates that these bioconstructions spend time at the sediment-water interface, similarly to mollusc shells, thus also acting as an important colonization surfaces for sclerobionts in a sand-dominant shelf.

During about 2000 years of sea-level rise, until the PSLM, the bryoliths were resedimented from the shoreface setting onto the transgressive foredunes, where they currently occur.

Currently, little is known about the contribution of bryoliths and rhodoliths to modern coastal dunes, or whether this type of formation is a prominent end point of bryolith/rhodolith taphonomy (Gulf of California, James et al., 2006, and Sewell et al., 2007; eastern Mediterranean, Titschack et al., 2008; Madeira Archipelago, Soares, 1973). The results of our study indicate that these coastal dunes can act as prominent end points in our study location. Further investigations on a wider range of modern and ancient coastal dune systems are required to identify the extent of and type of bryoliths/ macroids/rhodoliths and extensive bioclasts derived from bryozoans, encrusting foraminifera and coralline red algae.

\section{Acknowledgements}

We are grateful to the Coordenação de Aperfeiçoamento de Pessoal de Nível Superior-CAPES for providing postdoc fellowships (FTST and PSO). This study was financed in part by the Coordenação de Aperfeiçoamento de Pessoal de Nível Superior - Brasil (CAPES) - Finance Code 001. We thank the Universidade Federal do Rio Grande (FURG) for field and laboratory support. We are also grateful to Luiz Rota de Oliveira for donating some bryoliths studied herein. Rudmar Krumerick and Caroline Ruas (Centro de Microscopia Eletrônica do Sul (CEME-SUL), FURG) are thanked for the scanning electron microscopy (SEM) images of Brazilian specimens; Fabrizio Scarabino for the identification of some molluscs and Paulo Matioli for the MJNCA04 bryolith information. Ana Carolina Sousa de Almeida provided SEM of Biflustra arborescens specimens. Paul Taylor and Mary Spencer Jones provided SEM images of the comparative type material of bryozoans deposited at the Natural History Museum, London. Comments and suggestions from Matias Ritter and two anonymous reviewers improved the early version of the manuscript.

\section{Funding}

$\mathrm{KM}$ would like to thank Brazilian financial agencies CNPq (Conselho Nacional de Desenvolvimento Científico e Tecnológico,
307771/2017-2 and INCT-FNA, 464898/2014-5) and FAPERJ (Fundação Carlos Chagas Filho de Amparo à Pesquisa do Estado do Rio de Janeiro, E-26/110.138/2014 and E26/203.019/2016) for their financial support.

\section{ORCID iDs}

Frederico Tapajós de Souza Tâmega (iD) https://orcid.org/00000003-2773-2036

Kita Macario (iD) https://orcid.org/0000-0002-0581-9854

Davide Bassi (iD https://orcid.org/0000-0002-6833-9874

\section{References}

Adams H and Adams A (1854) Description of a new genus of bivalve Mollusca. Annals and Magazine of Natural History (Serie 2) 14: 418.

Agostini VO, Ritter MN, Macedo AJ et al. (2017) What determines sclerobiont colonization on marine mollusk shells? PLoS ONE 12(9): e0184745.

Aguirre J, Braga JC and Bassi D (2017) The role of rhodoliths and rhodolith beds in the rock record and their use in palaeoenvironmental reconstructions. In: Riosmena-Rodriguez $\mathrm{R}$, Nelson W and Aguirre J (eds) Rhodolith/Maerl Beds: A Global Perspective. Berlin: Springer-Verlag, pp. 105-138.

Aguirre ML, Richiano S, Álvarez MF et al. (2009) Malacofauna Cuaternaria del litoral nortede Santa Cruz (Patagonia, Argentina). Geobios 42: 411-434.

Almeida ACS, Souza F and Vieira LM (2017) Malacostegine bryozoans (Bryozoa: Cheilostomata) from Bahia State, northeast Brazil: Taxonomy and non-indigenous species. Marine Biodiversity 48: 1463-1488.

Alves E, Macario K, Ascough P et al. (2018) The worldwide marine radiocarbon reservoir effect: Definitions, mechanisms, and prospects. Reviews of Geophysics 56: 278-305.

Alves E, Macario K, Souza R et al. (2015) Radiocarbon reservoir corrections on the Brazilian coast from pre-bomb marine shells. Quaternary Geochronology 29: 30-35.

Angulo RJ, Lessa GC and de Souza MC (2006) A critical review of mid- to late-Holocene sea-level fluctuations on the eastern Brazilian coastline. Quaternary Science Reviews 25: 486-506.

Asp NE, Correa ICS and Calliari LJ (1999) Sea level changes and barrier system formation on inner continental shelf, Rio Grande do Sul, Brazil. Anais da Academia Brasileira de Ciência 71: 832-833.

Baarli BG, Santos A, da Silva CM et al. (2012) Diverse macroids and rhodoliths from the upper Pleistocene of Baja California Sur, Mexico. Journal of Coastal Research 28: 296-305.

Barbosa MM (1967) Conopeum commensale K.M., em depósito de maré, na Praia do Albardão, Santa Vitória do Palmar, RS (Bryozoa-Pleistoceno?). Anais da Academia Brasileira de Ciência 39: 279-283.

Bassi D, Carannante G, Checconi A et al. (2010) Sedimentological and palaeoecological integrated analysis of a Miocene canalized coralline red algal carbonate margin (Matese Mountains, Central-Southern Apennines, Italy). Sedimentary Geology 230: 105-122.

Bassi D, Carannante G, Murru M et al. (2006) Rhodalgal/bryomol assemblages in temperate type carbonate, channelised depositional systems: The Early Miocene of the Sarcidano area (Sardinia, Italy). In: Pedley HM and Carannante G (eds) Cool-Water Carbonates: Depositional Systems and Palaeoenvironmental Control, Vol. 255. London: Geological Society London (Special Publications), pp. 35-52.

Bassi D, Iryu Y, Braga JC et al. (2013) Bathymetric distribution of ichnocoenoses from Recent subtropical algal nodules off Fraser Island, eastern Australia. Palaeogeography, Palaeoclimatology, Palaeoecology 369: 58-66. 
Bassi D, Iryu Y, Humblet M et al. (2012) Recent macroids on the Kikai-jima shelf, Central Ryukyu Islands, Japan. Sedimentology 59: 2024-2041.

Bock P and Gordon D (2018) World register of marine species. Biflustra d'Orbigny 1852. Available at: http://marinespecies .org/aphia.php?p=taxdetails\&id=240919 (accessed 15 February 2018).

Bosence DWJ (1983) Description and classification of rhodoliths (rhodoids, rhodolites). In: Peryt TM (ed.) Coated Grains. Berlin: Springer, pp. 217-224.

Bromley RG and Asgaard U (1993) Endolithic community replacement on a Pliocene rocky coast. Ichnos 2: 93-116.

Bromley RG and D'Alessandro A (1983) Bioerosion in the Pleistocene of Southern Italy: Ichnogenera Caulostrepsis and Maeandropolydora. Rivista Italiana di Paleontologia e Stratigrafia 89: 283-309.

Bronk Ramsey C (2008) Deposition models for chronological records. Quaternary Science Reviews 27: 42-60.

Buchmann FS (1994) Distribuição dos fósseis pleistocênicos na zona costeira e plataforma continental interna no Rio Grande do Sul. Acta Geologica Leopoldensia 17: 355-364.

Buchmann FS and Tomazelli LJ (2003) Relict nearshore shoals of Rio Grande do Sul, southern Brazil: Origin and effects on nearby modern beaches. Journal of Coastal Research 35: 318-322.

Buchmann FS, Barbosa VP and Villwock JA (1998) Sedimentologia e paleoecologia durante o máximo transgressivo na Lagoa Mirim, RS, Brasil. Acta Geologica Leopoldensia 47: 21-26.

Buchmann FS, Seeliger M, Zanella LR et al. (2001) Análise batimétrica e sedimentológica no estudo do Parcel do Carpinteiro, uma paleolinha de praia pleistocênica na antepraia do Rio Grande do Sul, Brasil. Pesquisas em Geociências 28: $109-115$.

Busk G (1856) Zoophytology. Quarterly Journal of Microscopical Science 4: 176-179.

Calliari LJ and Klein AH (2011) Características morfodinâmicas e sedimentológicas das praias oceânicas entre Rio Grande e Chuí, RS. Pesquisas em Geociências 20: 45-56.

Calliari LJ, Tozzi HAM and Klein AHF (1998) Beach morphology and coastline erosion associated with storm surges. Anais da Academia Brasileira de Ciência 70: 232-247.

Canu F and Bassler RS (1928) Bryozaires du Brésil. Bulletin de la Société des Sciences de Seine-et-Oise 9: 58-100.

Chave KE (1954) Aspects of the biogeochemistry of magnesium 1. Calcareous marine organisms. Journal of Geology 62: 266-283.

Checconi A, Bassi D, Monaco P et al. (2010) Re-deposited rhodoliths in the Middle Miocene hemipelagic deposits of Vitulano (Southern Apennines, Italy): Coralline assemblage characterization and related trace fossils. Sedimentary Geology 225: 50-66.

Cherkinsky A, Culp RA, Dvoracek DK et al. (2010) Status of the AMS facility at the University of Georgia. Nuclear Instruments and Methods in Physics Research 268: 867-870.

Cook PL, Bock PE, Hayward PJ et al. (2018) Class Gymnolaemata, order Cheilostomata. In: Cook PL, Bock PE, Gordon DP and et al. (eds) Australian Bryozoa Volume 2: Taxonomy of Australian Families. Melbourne, VIC, Australia: CSIRO Publishing, pp. 61-280.

Cruz EA, Dillenburg SR and Buchmann FS (2016) Description and controls on distribution of Pleistocene vertebrate fossils from the central and southern sectors of the coastal plain of Rio Grande do Sul, Brazil. Revista Brasileirade Paleontologia 19: 425-438.

Cuffey RJ and Johnson ME (1997) Bryozoan nodules built around andesite clasts from upper Pliocene of Baja California: Palaeoecological implications and closure of the Panama Isthmus. In: Johnson ME and Ledesma-Vázquez J (eds) Pliocene Carbonates and Related Facies Flanking the Gulf of California, Baja California, Mexico. Boulder, CO: Geological Society of America (Special Publications 318), pp. 111-117.

Di Martino E and Taylor PD (2018) Early Pleistocene and Holocene bryozoans from Indonesia. Zootaxa 4419(1): 1-70.

Dillenburg SR, Esteves LS and Tomazelli LJ (2004) A critical evaluation of coastal erosion in Rio Grande do Sul, Southern Brazil. Anais da Academia Brasileira de Ciência 76: 611-623.

Dillenburg SR, Roy PS, Cowell PJ et al. (2000) Influence of antecedent topography on coastal evolution as tested by the shoreface translation-barrier model (STM). Journal of Coastal Research 16: 71-81.

Domènech R, Martinell J and Porta J (2008) Bioerosión por poliquetos espíonidos (Polychaeta, Spionidae) en moluscos marinos del Cuaternario caribẽno de Colombia. Revista de la Academia Colombiana de Ciencias Exactas, Físicas y Naturales 32: 411-419.

El-Sorogy AS (2015) Bryozoan nodules as a frame-builder of bryozoan-microreef, middle Miocene sediments, Egypt. Journal of Earth Science 26: 251-258.

Fachin S (1998) Caracterização do perfil de equilibrio da ante praia na costa do Rio Grande do Sul. MS Thesis, Universidade Federal do Rio Grande do Sul.

Figueiredo AG (1975) Geologia dos depósitos calcários biodetríticos da plataforma continental do Rio Grande do Sul. MS Thesis, Universidade Federal do Rio Grande do Sul.

Foster MS (2001) Rhodoliths: Between rocks and soft places. Journal of Phycology 37: 659-667.

Glynn PW (1974) Rolling stones amongst the Scleractinia: Mobile coralliths in the Gulf of Panama. In: Proceedings of the 2nd International Coral Reef Symposium, Brisbane, QLD, Australia, December, vol. 2, pp. 183-198. Brisbane, QLD, Australia: Great Barrier Reef Committee.

Graham DJ and Midgley NG (2000) Graphical representation of particle shape using triangular diagrams: An Excel spreadsheet method. Earth Surface Processes and Landforms 25: 1473-1477.

Henriques MCMO, Riosmena-Rodriguez R, Coutinho LM et al. (2014) Lithophylloideae and Mastophoroideae (Corallinales, Rhodophyta) from the Brazilian continental shelf. Phytotaxa 190: 112-129.

Hottinger L (1983) Neritic macroid genesis, an ecological approach. In: Peryt TM (ed.) Coated Grains. Berlin: SpringerVerlag, pp. 38-55.

James DW, Foster MS and O'Sullivan J (2006) Bryoliths (Bryozoa) in the Gulf of California. Pacific Science 60: 117-124.

Johnson ME, Baarli BG, Cachão M et al. (2012) Rhodoliths, uniformitarianism, and Darwin: Pleistocene and recent carbonate deposits in the Cape Verde and Canary archipelagos. Palaeogeography, Palaeoclimatology, Palaeoecology 329-330: 83-100.

Kempf M (1980) Perspectiva de exploração econômica dos fundos de algas calcárias da plataforma continental do nordeste do Brasil. Trabalhos do Instituto Oceanográfico da Universidade Federal de Pernambuco 15: 139-164.

Kempf M, Coutinho PN and Morais JO (1969) A Plataforma continental do norte e nordeste do Brasil: Nota preliminar sobre a natureza do fundo. Trabalhos do Instituto Oceanográfico da Universidade Federalde Pernambuco 9: 9-15.

Kidwell SM and Gyllenhaal ED (1998) Symbiosis, competition, and physical disturbance in the growth histories of Pliocene cheilostome bryoliths. Lethaia 31: 221-239.

Kirkpatrick R and Metzelaar J (1992) On an instance of commensalism between a hermit crab and a Polyzoon. In: Proceedings of the Zoological Society of London 92: 983-990. 
Kitahara MV, Capítoli RR and Horn Filho NO (2009) Distribution of deep-sea azooxanthellate scleractinians from southern Brazilian waters. Iheringia Série Zoologia 99: 223-236.

Klicpera A, Taylor PD and Westphal H (2013) Bryoliths constructed by bryozoans in symbiotic associations with hermit crabs in a tropical heterozoan carbonate system, Golfe d'Arguin, Mauritania. Marine Biodiversity 54: 429-444.

Kohler KE and Gill SM (2006) Coral Point Count with Excel extensions (CPCe): A visual basic program for the determination of coral and substrate coverage using random point count methodology. Computers \& Geosciences 32: 1259-1269.

Kuklinski P and Taylor PD (2009) Mineralogy of Arctic bryozoan skeletons in a global context. Facies 55: 489-500.

Lamarck JB (1801) Système des animaux sans vertèbres ou tableau général des classes, des ordres et des genres de ces animaux. Paris: Déterville.

Lamarck JB (1819) Histoire naturelle des animaux sans vertèbres, présentant les caractères généraux et particuliers de ces animaux, leur distribution, leurs classes, leurs familles, leurs genres et la citation des principales espèces qui s'y rapportent. Paris: Verdière.

Lima LG, Dillenburg SR, Medeanic S et al. (2013) Sea-level rise and sediment budget controlling the evolution of a transgressive barrier in southern Brazil. Journal of South American Earth Sciences 42: 27-38.

Lima SF, Almeida LESB and Toldo EE, Jr (2001) Estimate of longshore sediments transport from waves data to the Rio Grande do Sul coast. Pesquisas 28: 99-107.

Lopes RP (2013) Biostratigraphy of the Pleistocene fossiliferous deposits of the southern Brazilian coastal area. Journal of Mammalian Evolution 20: 69-82.

Macario KD, Alves EQ, Moreira VN et al. (2017) Fractionation in the graphitization reaction for ${ }^{14} \mathrm{C}$-AMS analysis: The role of $\mathrm{Zn} \times$ the role of TiH2. International Journal of Mass Spectrometry 423: 39-45.

Macario KD, Oliveira FM, Carvalho C et al. (2015) Advances in the graphitization protocol at the Radiocarbon Laboratory of the Universidade Federal Fluminense (LAC-UFF) in Brazil. Nuclear Instruments and Methods in Physics Research Section B: Beam Interactions with Materials and Atoms 361: 402-405.

Marcus E (1937) Bryozoários marinhos brasileiros, 1. Boletim da Faculdade de Filosofia Ciências e Letras da Universidade de São Paulo Zoologia 1: 5-224.

Marrack EC (1999) The relationship between water motion and living rhodolith beds in the southwestern Gulf of California, Mexico. Palaios 14: 159-171.

Martin L, Suguio K and Flexor JM (1979) Le Quaternaire marin du littoral brésilien entre Cananéia (SP) et Barra de Guaratiba (RJ). In: Proceedings of the International Symposium on Coastal Evolution in the Quaternary (eds K Suguio, TR Fairchild and L Martin), São Paulo, Brazil, 11-18 September, pp. 296-331. São Paulo, Brazil: EDUSP.

Martinell J and Domènech R (2009) Commensalism in the fossil record: Eunicid polychaete bioerosion on Pliocene solitary corals. Acta Paleontologica Polonica 54: 143-154.

Martínez S, del Río CJ and Rojas A (2013) Quaternary mollusks. In: Martínez S, del Río CJ and Rojas A (eds) Biogeography of the Quaternary Molluscs of the Southwestern Atlantic ocean (Springer Briefs in Earth System Sciences). Dordrecht: Springer, pp. 17-32.

Martínez S, Ubilla M, Verde M et al. (2001) Paleoecology and geochronology of Uruguayan coastal marine Pleistocene deposits. Quaternary Research 55: 246-254.

Moissette P, Cornée JJ and Koskeridou E (2010) Pleistocene rolling stones or large bryozoan nodules in a mixed siliciclasticcarbonate environment (Rhodes, Greece). Palaios 25: 24-39.
Nebelsick JH (1996) Encrustation of small substrates in Tertiary limestones and their importance for carbonate sedimentation. In: Reitner J, Neuweiller F and Gunkel F (eds) Global and Regional Controls on Biogenic Sedimentation. I. Reef Evolution. Gottingen: Gottinger Arbeiten zur Geologie und Paläontologie, pp. 161-167.

Nishizawa Y (1985) Multilaminar colonies of bryozoans from Japan. I. 'Ectoproctalith' of Antropora tincta (Hastings). In: Transactions and Proceedings of the Paleontological Society of Japan (New series), Tokyo, Japan, 30 April, pp. 19-24. Tokyo, Japan: Palaeontological Society of Japan.

Parise CK, Calliari LJ and Krusche N (2009) Extreme storm surges in the south of Brazil: Atmospheric conditions and shore erosion. Brazilian Journal of Oceanography 57: 175-188.

Peryt TM (1983) Classification of coated grains. In: Peryt TM (ed.) Coated Grains. Berlin: Springer-Verlag, pp. 3-6.

Philippi RA (1836) Beschreibung einiger neuen ConchylienArten und Bemerkungen über die Gattung Lacuna von Turton. Archiv für Naturgeschichte 2: 224-235, pls. 7-8.

Prager EJ and Ginsburg RN (1989) Carbonate nodule growth on Florida's outer shelf and its implications for fossil interpretations. Palaios 4: 310-317.

Prieto AR, Mourelle D, Peltier WR et al. (2017) Relative sealevel changes during the Holocene in the Río de la Plata, Argentina and Uruguay: A review. Quaternary International 442: 35-49.

Ramalho LV and Calliari LJ (2015) Bryozoans from Rio Grande do Sul continental shelf, Southern Brazil. Zootaxa 3955: 569-587.

Reimer PJ, Bard E, Bayliss A et al. (2013) IntCal13 and Marine13 radiocarbon age calibration curves $0-50,000$ years cal B.P. Radiocarbon 55: 1869-1887.

Rios EC (2009) Compendium of Brazilian Seashells. Rio Grande, Brazil: Editora Evangraf.

Ritter MN, Erthal F, Kosnik MA et al. (2017) Spatial variation in the temporal resolution of subtropical shallow-water molluscan death assemblages. Palaios 32: 572-583.

Romero MV, Brezina SS, Hernández D et al. (2013) Differential settlement of associated species on Ostrea puelchana d'Orbigny, 1842 (Ostreidae) in Patagonia (Argentina). American Malacological Bulletin 31: 311-320.

Rosa MLCC, Barboza EG, Abreu VS et al. (2017) High-frequency sequences in the Quaternary of Pelotas basin (coastal plain): A record of degradational stacking as a function of longer-term base-level fall. Brazilian Journal of Geology 47: 183-207.

Scholz J (2000) Eine Feldtheorie der bryozoen, mikrobenmattenund sedimentoberflächen. Abhandlungender Senckenbergische Naturforschendengesellschaft 552: 1-193.

Sewell AA, Johnson ME, Backus DH et al. (2007) Rhodolith detritus impounded by a coastal dune on Isla Coronados, Gulf of California. Ciencias Marinas 33: 483-494.

Smith AM, Key MM, Jr and Gordon DP (2006) Skeletal mineralogy of bryozoans: Taxonomic and temporal patterns. EarthScience Reviews 78: 287-306.

Smith AM, Nelson CS and Spencer HG (1998) Skeletal carbonate mineralogy of New Zealand bryozoans. Marine Geology 151: $27-46$.

Soares F (1973) A formaçãoeolianítica da Ilha do Porto Santo. Memórias e Notícias Publicações do Museu Mineralógico e Geológico da Universidade de Coimbra 75: 47-88.

Sokal RR and Rohlf FJ (1995) Biometry: The Principles and Practice of Statistics in Biological Research. New York: W.H. Freeman.

Sowerby I in Broderip WJ and Sowerby GB (1833) The collection of shells formed by Mr. Cuming on the western coast of South America, and among the islands of the Southern Pacific Ocean. In: Proceedings of the Committee of Science and Correspondence of the Zoological Society of London 2: 194-202. 
Spjeldnaes N and Moissette P (1997) Celleporid (bryozoan) thickets from the Upper Pliocene of the Island of Rhodes, Greece. In: James NP and Clarke JAD (eds) Cool-Water Carbonates. Tulsa, OK: SEPM (Special Publication 56), pp. 263-270.

Suguio K, Barreto AMF, De Oliveira PE et al. (2013) Indicators of Holocene sea level changes along the coast of the states of Pernambuco and Paraíba, Brazil. Geologia USP: Série Científica 13: 141-152.

Tâmega FTS, Bassi D, Figueiredo MAO et al. (2014) Deep-water rhodolith bed from central Brazilian continental shelf, Campos Basin: Coralline algal and faunal taxonomic composition. Galaxea 16: 21-31.

Tâmega FTS, Spotorno-Oliveira P and Figueiredo MAO (2013) Catalogue of the Benthic Marine Life from Peregrino Oil Field, Campos Basin, Brazil. Rio de Janeiro, Brazil: Instituto Biodiversidade Marinha.

Taylor PD and Tan S-HA (2015) Cheilostome bryozoa from Penang and Langkawi, Malaysia. European Journal of Taxonomy 149: $1-34$.

Taylor PD and Wilson MA (2003) Palaeoecology and evolution of marine hard substrate communities. Earth-Science Reviews 62: 1-103.

Taylor PD, James NP, Bone Y et al. (2009) Evolving mineralogy of cheilostome bryozoans. Palaios 24: 440-452.

Taylor PD, Lombardi C and Cocito S (2015) Biomineralization in bryozoans: Present, past and future. Biological Reviews 90: $1118-1150$.

Titschack J, Nelson CS, Beck T et al. (2008) Sedimentary evolution of a Late Pleistocene temperate red algal reef (Coralligéne) on Rhodes, Greece: Correlation with global sea-level fluctuations. Sedimentology 55: 1747-1776.

Toby BH and Von Dreele RBJ (2013) GSAS-II: The genesis of a modern open-source all-purpose crystallography software package. Journal of Applied Crystallography 46: 544-549.
Toldo EE, Jr, Nicolodi J, Almeida L et al. (2006) Coastal dunes and shoreface width as a function of longshore transport. Journal of Coastal Research 39: 390-394.

Tomazelli LJ and Villwock JA (1996) Quaternary geological evolution of Rio Grande do Sul coastal plain, southern Brazil. Anais da Academia Brasileira de Ciências 68: 373-382.

Tomazelli LJ, Dillenburg SR and Villwock JA (2000) Late quaternary geological history of Rio Grande do Sul coastal plain, southern Brazil. Revista Brasileira de Geociências 30: 470-472.

Tozzi HAM and Calliari LJ (2000) Morfodinâmica da Praia do Cassino, RS. Pesquisas em Geociências 27: 29-42.

Vieira LM, Almeida ACS and Winston JE (2016) Taxonomy of intertidal cheilostome Bryozoa of Maceió, northeastern Brazil. Part 1: Suborders Inovicellina, Malacostegina and Thalamoporellina. Zootaxa 4097: 59-83.

Vieira LM, Migotto AE and Winston JE (2008) Synopsis and annotated checklist of Recent marine Bryozoa from Brazil. Zootaxa 1810: 1-39.

Wiener MH (2012) Problems in the measurement, calibration, analysis, and communication of radiocarbon dates (with special reference to the prehistory of the Aegean world). Radiocarbon 54: 423-434.

Wilson MA, Ozanne CR and Palmer TJ (1998) Origin and paleoecology of free-rolling oyster accumulations (ostreoliths) in the middle Jurassic of southwestern Utah, USA. Palaios 13: 70-78.

Xu X, Trumbore SE, Zheng S et al. (2007) Modifying a sealed tube zinc reduction method for preparation of AMS graphite targets: Reducing background and attaining high precision. Nuclear Instruments and Methods in Physics Research B: Beam Interactions with Materials and Atoms 259: 320-329.

Zabin CJ, Obernolte R, Mackie JA et al. (2010) A non-native bryozoan creates novel substrate on the mudflats in San Francisco Bay. Marine Ecology Progress Series 412: 129-139.

Zar JH (1999) Biostatistical Analysis. London: Prentice Hall International. 